\title{
Isotopic Disequilibrium among Commingled Hybrid Magmas: Evidence for a Two-Stage Magma Mixing-Commingling Process in the Mt. Perkins Pluton, Arizona ${ }^{1}$
}

\author{
Rodney V. Metcalf, Eugene I. Smith, J. Douglas Walker, ${ }^{2}$ \\ Randal C. Reed, and David A. Gonzales ${ }^{2}$ \\ Department of Geoscience, University of Nevada, Las Vegas, NV 89154.4010
}

\begin{abstract}
The syn-extensional Miocene Mt. Perkins pluton, northwestern Arizona, cooled rapidly due to its small size $\left|6 \mathrm{~km}^{2}\right|$ and shallow emplacement $(7.5 \mathrm{~km})$ and allows examination of commingled rocks that experienced little isotopic exchange. Within the pluton, quartz dioritic to granodioritic host rocks $\left(58-68 \mathrm{wt} \% \mathrm{SiO}_{2}\right)$ enslose dioritic enclaves $\left(50-55 \mathrm{wt} \% \mathrm{SiO}_{2}\right)$ and a portion contains enclave-free granodiorite $\left(70-74 \mathrm{wt} \% \mathrm{SiO}_{2}\right)$. Fine-grained, crenulate enclave margins and a lack of advanced mixing structures (c.g., schlicren, flow fabrics, etc.) indicate an incipient stage of commingling. Isotopic variation between enclaves and enclosing host rocks is large $\left\{6.8\right.$ to $10.6 \epsilon_{\mathrm{Nd}}$ units; 0.0036 to $0.0046^{87} \mathrm{Sr} /{ }^{86} \mathrm{Sr}$ units), suggesting isotopic disequilibrium. Comparison of an enclave core and rim suggests that isotopic exchange with the host magma was limited to the enclave rim. Enclaves and hosts collectively form a calc-alkaline suite exhibiting a large range of $\epsilon_{\mathrm{Na}}(+1.2$ to -12.5$)$ and initial ${ }^{87} \mathrm{Sr} /{ }^{86} \mathrm{Sr}(0.705$ to 0.71267$)$ with a correlation among $\epsilon_{\mathrm{Nd}}$, initial ${ }^{87} \mathrm{Sr} /{ }^{86} \mathrm{Sr}$, and major and trace element compositions. Modeling sugests that the suite formed by magma hybridization involving magma mixing accompanied by fractional crystallization. The magma mixing must have predated commingling at the present exposure level and indicates a larger mixing chamber at depth. Isotopic and trace element data suggests mixing end-members were asthenospheric mantle-derived mafic and crustal-derived felsic magmas. Fractional crystallization facilitated mixing by reducing the rheological contrasts between the mafic and felsic mixing end-members.
\end{abstract}

\section{Introduction}

Magma mixing is a progressive process that begins with interaction (commingling) of two magmas (liquid-crystal mixtures) with initially different thermal, rheological, and compositional characteristics. At completion, the process can result in hybrid magmas with compositions intermediate between the mixing end-members (Eichelberger 1975; Barbarin and Didier 1992). The petrogenetic and tectonic significance of magma mixing primarily depends on the source of the end-member magmas. Relatively homogeneous intermediate hybrid rocks, however, provide little direct evidence of their mixing end-members.

Upon commingling, temperatures of the different magmas rapidly. equilibrate. Seaman and Ram\footnotetext{
1995.

${ }^{1}$ Manuscript received January 20, 1995; accepted May 10,

${ }^{2}$ Isotope Geochemistry Laboratory, University of Kansas, Lawrence KS, 66045.
}

sey (1992) estimated that it takes $33 \mathrm{hrs}$ for a $10 \cdot \mathrm{cm}$ mafic enclave to equilibrate thermally with a felsic host magma. Thermal equilibration promotes rapid crystallization in the more mafic magma and dissolution of crystals in the more felsic magma. Subsequent interaction between the two magmas may involve mechanical stirring (blending) as well as isotopic and chemical diffusion. The relative and absolute viscosities of the two magmas after thermal equilibration determines whether mechanical stirring is rheologically possible (Sparks and Marshall 1986). Viscosities, in turn, depend on magma compositions, crystal contents, equilibration temperature, and volatile contents of the commingled magmas. Mechanical stirring promotes magma hybridization by the dispersal of crystals and liquids from one magma into the other and accelerates chemical and isotopic equilibration by increasing the surface area between the magmas.

Mafic microgranitoid enclaves within more fel- 
sic granitoid host rocks, common features in plutonic rocks world-wide, are evidence of magma commingling and represent an early stage of the magma mixing process (Vernon 1983, 1984; Frost and Mahood 1984; Pitcher 1991; Wiebe 1991). Evaluation of end-member magma sources is often based on $\mathrm{Nd}$ and $\mathrm{Sr}$ isotopic studies of enclaves and their host rocks. Post-commingling isotopic diffusion (Baker 1989; Lesher 1990, 1994), however, is capable of modifying the isotopic composition of commingled magmas. In addition, enclaves and host rocks may represent hybrid magmas formed by a number of pre-commingling processes including fractional crystallization, assimilation, and magma mixing, or a combination of these. Based on microstructural evidence, Vernon $(1984,1990)$ argued that many mafic microgranitoid enclaves are hybrids formed by previous open-system magmatic processes, probably magma mixing. Koyaguchi (1986) interpreted dacite enclaves within rhyolite domes on Niijima Island, Japan, as hybrid magmas formed by mixing of rhyolite and basalt. Davidson et al. (1990) used $\mathrm{Nd}$ and $\mathrm{Sr}$ isotopes to document the commingling of dacite hybrid magma with basaltic-andesite hybrid magma; both hybrid magmas formed primarily by mixing of mantle-derived mafic and crustal-derived felsic magmas. Magma mixing is complex and may involve several stages with multiple comminglingmixing events each occurring at a different level in the crust (cf. Barbarin 1991). Both pre-commingling hybridization and post-commingling isotopic diffusion hinter the recognition and evaluation of endmember magmas.

The nature of original end-members may still be assessed even when enclaves are formed by commingling hybrid magmas, provided that postcommingling isotopic diffusion was minimal. The extent to which diffusion can bring about chemical and isotopic equilibration depends primarily upon the diffusion rates of individual chemical and isotopic components and the distances and time over which diffusion operates. A rapidly cooled pluton that experienced little or no isotopic diffusion therefore should provide the best opportunity for evaluating end-member magma sources using enclave-host rock data.

In this paper we present geochemical data, including $\mathrm{Nd}$ and $\mathrm{Sr}$ isotopes, for commingled rocks of the Miocene Mt. Perkins pluton, northwestern Arizona. Rapid cooling related to the pluton's small size and shallow emplacement, combined with a lack of mechanical mixing, prevented appreciable isotopic exchange among the commingled magmas. The pluton exhibits a large range of isoto- pic compositions that varies with whole rock composition. Measured enclave-host isotopic differences are some of the largest reported to date. The preservation of pre-commingling isotopic compositions allows for evaluation of the magmatic evolution of the suite.

\section{Regional Geology}

The Miocene Mt. Perkins pluton, central Black Mountains of northwestern Arizona (figure 1), lies within the northern Colorado River extension corridor (NCREC), a portion of the Basin and Range province (Faulds et al. 1990). Magmatism accompanying Cenozoic extension in the Basin and Range can be divided into two broad categories: an older sequence of calc-alkalic intermediate to silicic rocks and a younger group of basalts and bimodal suites of basalt and rhyolite (Christensen and Lipman 1972). This trend is reflected within the NCREC as a change from intermediate calc-alkalic and alkali-calcic magmatism during mid- to lateMiocene time to eruptions of compositionally restricted tholeiitic and alkalic basalts in Pliocene time. Calc-alkalic intermediate magmatism (23-11 Ma) began prior to and continued during a period of active block-faulting; tholeiitic to alkalic magmas (11-4 Ma) were erupted after significant block-faulting (Feuerbach et al. 1993; Faulds et al. 1994).

Numerous Miocene plutons, including the Newberry, Searchlight, Aztec Wash, Nelson, Mt. Perkins and Wilson Ridge plutons, are exposed within the NCREC. On the basis of trace element modeling, Smith et al. (1990) and Larsen and Smith (1991) showed that intermediate rocks in the Wilson Ridge pluton (13.4 Ma) and the cogenetic River Mountains volcano represent hybrid magmas derived primarily by mixing of mafic and felsic endmembers rather than the result of fractionation from a common parent. The addition of $\mathrm{Nd}$ and $\mathrm{Sr}$ isotope data confirms this interpretation (Feuerbach et al. 1993; Metcalf et al. 1993|. C. F. Miller and coworkers (Falkner et al. 1995; Miller et al. 1994) have drawn a similar conclusion regarding intermediate rocks in the Aztec Wash pluton (15.7 Ma, Falkner et al. 1995). In both suites, data suggests that lithospheric mantle-derived mafic magma and crustal-derived felsic magma served as mixing end-members.

\section{Geology of the Mt. Perkins Pluton}

The Mt. Perkins Pluton (figure 1 ) is a small, compositionally variable body that is elongate parallel to nearby $\mathrm{N} \cdot \mathrm{NW}$ trending Miocene normal faults. 


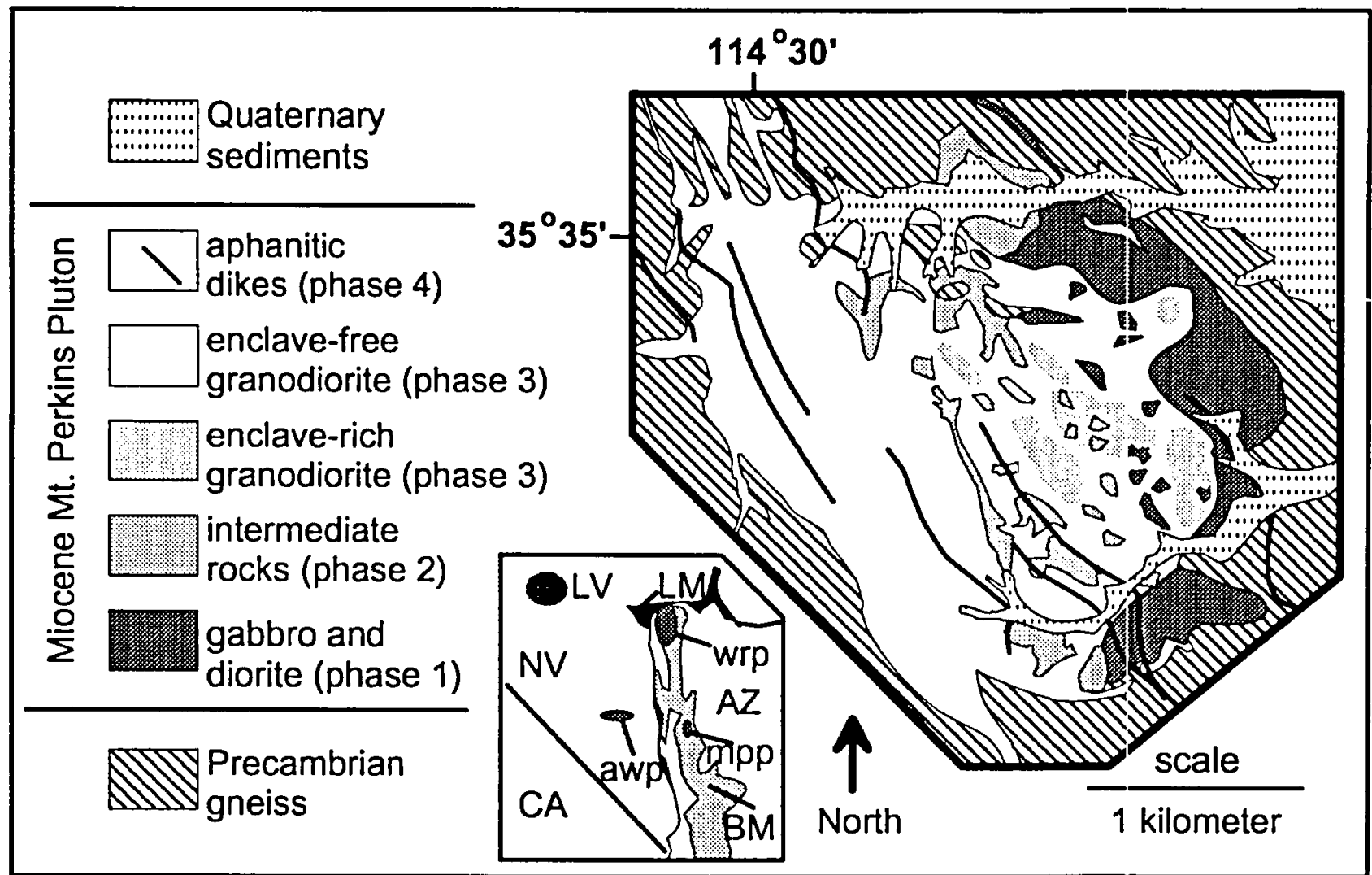

Figure 1. Geologic map of the Miocene Mt. Perkins pluton, simplified from 1:12000 scale mapping by R. V. Metcalf and R. C. Reed. Insert shows locations of the Mt. Perkins pluton (mpp), Aztec Wash pluton (awp), and Wilson Ridge pluton (wrp) within the northern Colorado River extensional corridor (BM = Black Mountains; $L M=$ Lake Mead; $\mathrm{LV}=$ Las Vegas; $\mathrm{NV}=$ Nevada; $\mathrm{CA}=$ California $\mathrm{AZ}=$ Arizona $)$.

Field relationships discussed in the following section reveal a four-phase emplacement history. The oldest unit, phase 1 , consists of coarse-grained hornblende gabbro (figure $2 a$ ). Phase 2 consists of mafic enclaves composed of fine-grained diorite contained within medium-grained, granodiorite to quartz diorite host rocks (figure $2 b$ ). Some phase 2 outcrops consist of fine- to medium-grained, enclave-free granitoid rock of quartz monzodiorite to diorite composition. Phase 3 is largely felsic in composition and is subdivided into mafic enclaverich zones and enclave-free zones. In the enclavefree zones, phase 3 granitoid rocks consist of finegrained, biotite granodiorite to granite. Phase 3 host rocks in the enclave-rich zones consist of hornblende-bearing biotite granodiorite to granite (figure $2 c$ ). Phase 4 is composed of numerous N-NW striking planar aphanitic dikes of mafic, in. termediate and felsic compositions (figure $2 b$ ).

Mafic enclaves in phases 2 and 3 range in size from a few centimeters to several meters across and make up 30 to $70 \%$ of outcrops. Enclaves in phase 2 tend to be smaller and more numerous at the outcrop scale compared to those in phase 3. Enclaves have ovoid, pillow-like shapes commonly bounded by crenulate margins (figure $2 c$ ). Crenulate margins are finer-grained than enclave interiors (figure $2 c$ ). Micro-enclaves are present within the host rocks in enclave-rich phase 3 and the more felsic host rocks of phase 2 . These micro-enclaves are ovoid-shaped masses, several millimeters to centimeters in diameter, compositionally similar to mafic enclaves (figure $2 c$ ).

Emplacement History. Cross-cutting and xenolith relationships suggest that phases 1 to 4 were emplaced as a sequence of separate magma pulses over a protracted interval of time. Each magma pulse solidified prior to emplacement of subsequent magma batches. Phase 4 consists of planar dikes that cut the other three phases and is clearly the youngest of the four units (figures 1 and $2 b$ ). Phase 1 gabbro forms the eastern margin of the pluton and also occurs in a belt of angular meso- to megascopic xenoliths within phases 2 (mesoscale only) and 3 rocks (figures 1 and $2 a$ ). In addition, intrusive contacts between Precambrian country 
Figure 2. (a) Angular xenoliths of phase 1 gabbro contained within enclave-free phase 3 granite. $|b|$ Outcrop of enclave-rich intermediate phase 2 cut by a granite dike of enclave-free phase 3 , which in turn is cut by an aphanitic basaltic dike of phase 4 (labeled P4). Note that phase 3 granite is considerably more leucocratic than the intermediate host rock in phase 2. (c) Enclave-rich phase 3; note the dark, fine-grained (chilled) crenulate margin (white arrows) on the melanocratic mafic enclave; also note the dark microenclaves (black arrows) within the leucocratic granite host.

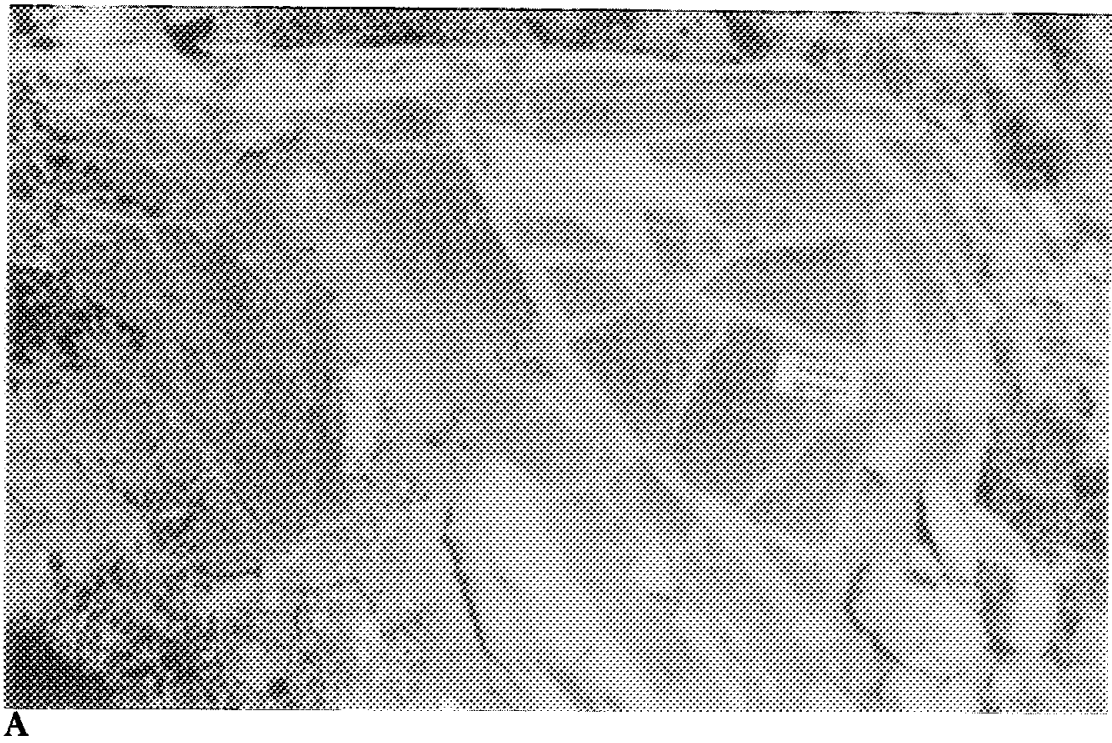

A
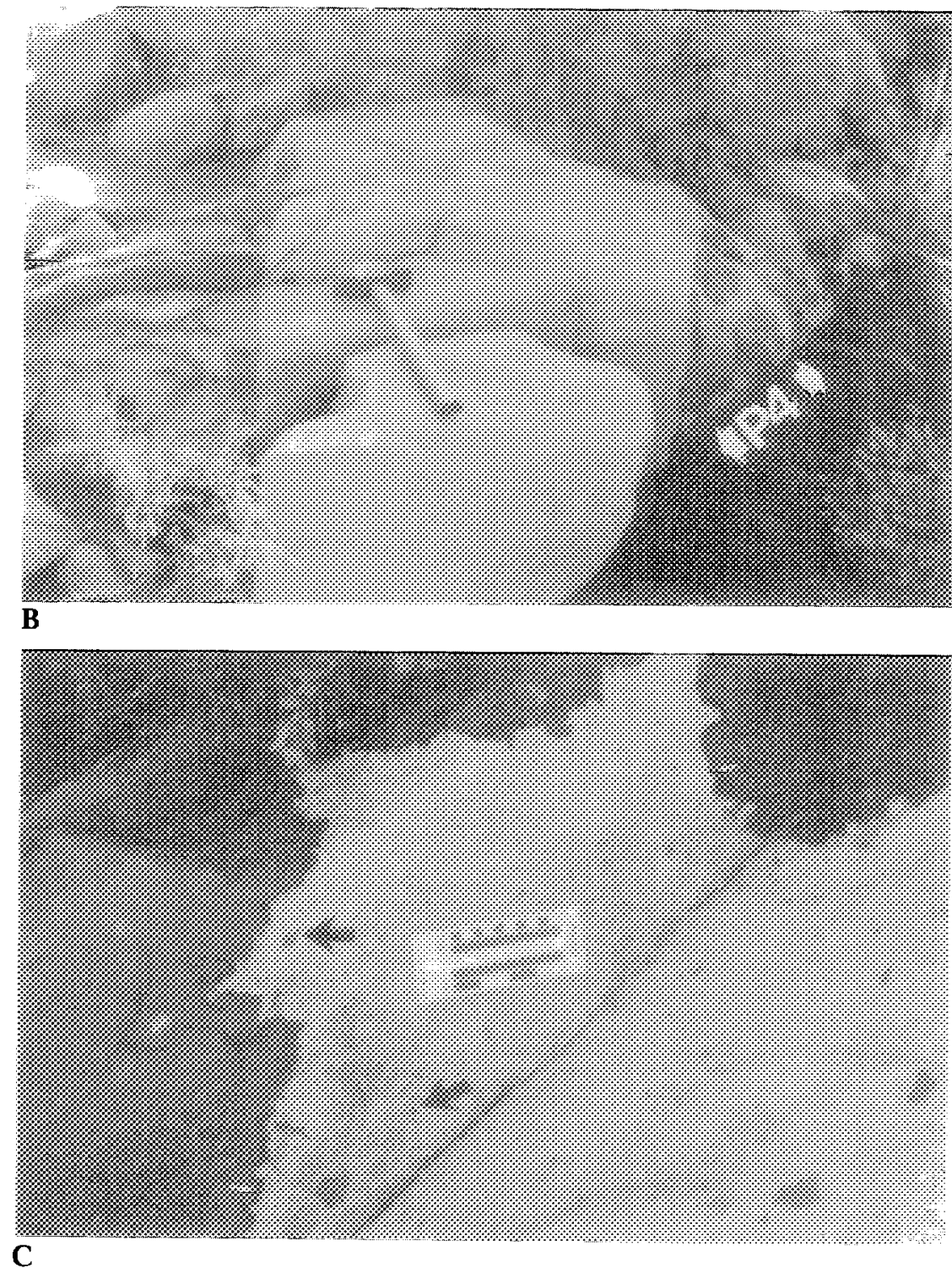
rocks and phase 1 gabbro are cut by both phases 2 and 3 bodies (figure 1). Phase 1 gabbro, therefore, represents the oldest intrusive unit within the pluton. Phase 2 rocks occur as a belt of megascopic xenolithic blocks within the eastern portion of phase 3 , west of the outcrop area of phase 1 (figure 1). Enclave-free phase 3 cuts phase 2 as dikes (figure $2 b$ and also cuts intrusive contacts between phases 1 and 2 (figure 1). Phase 2, therefore, is the second oldest unit within the pluton. Phase 3 constitutes the largest volume of the pluton, with enclave-rich portions concentrated on the eastern side of the pluton (figure 1 and $2 c$ ) and enclave-free portions making up the western one-third of the body. Apparently the locus of magma emplacement shifted from what is now the eastern margin of the pluton toward the west with time. Faulds (1993) reported an ${ }^{40} \mathrm{Ar} /{ }^{39} \mathrm{Ar}$ biotite age of $15.96 \pm$ $0.06 \mathrm{Ma}$ for a sample taken from phase 3 .

The presence of numerous xenoliths of Precambrian gneiss and of older Mt. Perkins phases within younger phases, together with an overall N-NWstriking geometry, suggests that the pluton was emplaced by stoping, perhaps in conjunction with syn-magmatic extension. Pluton emplacement occurred immediately prior to the onset of major extension in the area (Faulds 1994). Preliminary Alin-hornblende geobarometry indicates a shallow level of emplacement for phases 2 and 3 (Schmidt, 1992 calibration; $\mathrm{P}=2.05 \pm 0.6 \mathrm{kbars}$, depth $=$ $7.5 \pm 2.2 \mathrm{~km}$, Metcalf and Smith 1991 and unpublished data). Structural and paleomagnetic data suggest $40^{\circ}$ to $90^{\circ}$ of westward tilting subsequent to pluton emplacement (Faulds et al. 1990). Phase 1 gabbro is composed in part of olivine, clinopyroxene, and plagioclase cumulate minerals. Previous isotopic work on phase 1 rocks revealed a complex history with an uncertain genetic relationship to phases 2 and 3 (Metcalf et al. 1993). Phase 4 dikes are hydrothermally altered and have not been studied in detail although they bear a number of similarities to phase 2 and 3 rocks including commingling features. Compositional similarities and the common presence of commingling features in phases 2 and 3 suggest a genetic relationship; the remainder of this paper deals only with the petrogenesis in phases 2 and 3.

Petrography. Phase 2 and 3 enclaves are diorites composed primarily of plagioclase and hornblende with minor amounts of quartz and orthoclase. Biotite is present in some but not all enclave samples. Accessory minerals include titanite, opaque oxides, and apatite. Trace amounts of resorbed clinopyroxene are present in some enclaves (figure $3 a$ ). Enclaves exhibit igneous microstructures includ. ing lath-shaped subhedral to euhedral plagioclase showing a strong complex, internal euhedral zoning, prismatic subhedral to euhedral hornblende and acicular apatite crystals (figure $3 a, b$ ).

Granodiorite to granite in the enclave-free portion of phase 3 is composed primarily of plagioclase, orthoclase, and quartz. Biotite $(3-8 \%)$ is the sole mafic mineral. Accessory minerals include apatite, opaque oxides, and zircon, but titanite is absent. Plagioclase in these rocks is subhedral to euhedral and exhibits a weak. internal euhedral zoning. Granodiorite to granite host rocks in enclave-rich phase 3 differ from that of enclave-free areas by the presence of hornblende $(5-8 \%)$ and titanite. Hornblende occurs in two forms: (1) single subhedral to euhedral crystals; and (2) fine-grained millimeter scale micro-enclaves composed primarily of hornblende and opaque oxides, \pm plagioclase (figure 3c). The more felsic (granodiorite) host rocks in phase 2 are similar to host rocks in enclave-rich portions of phase 3 except that the former has a greater abundance of mafic minerals and slightly less quartz.

Phase 2 quartz monzodiorite to diorite (intermediate host rocks and enclave-free granitoid rocks) are composed primarily of plazioclase, hornblende with variable amounts of biotite, quartz, and orthoclase. Accessory minerals include titanite, opaque oxide, and apatite. Plagioclase is subhedral to euhedral and exhibits complex internal euhedral zoning. Hornblende occurs primarily as individual sub- to euhedral grains. Micro-enclaves are rare in these rocks and are restricted to more felsic compositions.

\section{Geochemistry}

Analytical Methods. Eighteen fresh whole-rock samples collected from phases 2 and 3 were analyzed for major and selected trace elements (table 1) by x-ray fluorescence spectrometry at the University of Nevada, Las Vegas. Additional trace element data (table 1) were collected on 16 of the samples by instrumental neutron activation analysis at the Phoenix Memorial Laboratory at the University of Michigan. Neodymium and Sr isotopic analyses (table 1) were done on 17 of the samples by thermal ionization mass spectrometry at the University of Kansas. Analytical procedures for each of the techniques used in this study are the same as those described in Feuerbach et al. (1993). The sample suite includes five sets of paired enclavehost rock samples collected from single outcrops, plus intermediate to felsic granitoid rocks collected from enclave-free areas (table 1). During 
Figure 3. Photomicrographs showing enclave mineralogy and textures: $\{a \mid$ phase 2 enclave (sample 924-4) containing anhedral (resorbed) clinopyroxene grains (labeled $\mathrm{Cl}$ and acicular grains of apatite (labeled A), plane polarized light; $(b)$ phase 3 enclave (sample 924-2) displaying igneous microstructures, specifically subhedral to euhedral grains of hornblende (labeled $\mathrm{H}$ ) and lath-shaped plagioclase (labeled P|, crossed polars; (c) Microenclave contained within phase 3 enclave-rich granite host rock; micro-enclave is composed primarily of hornblende and opaque oxide with minor plagioclase, crossed polars.

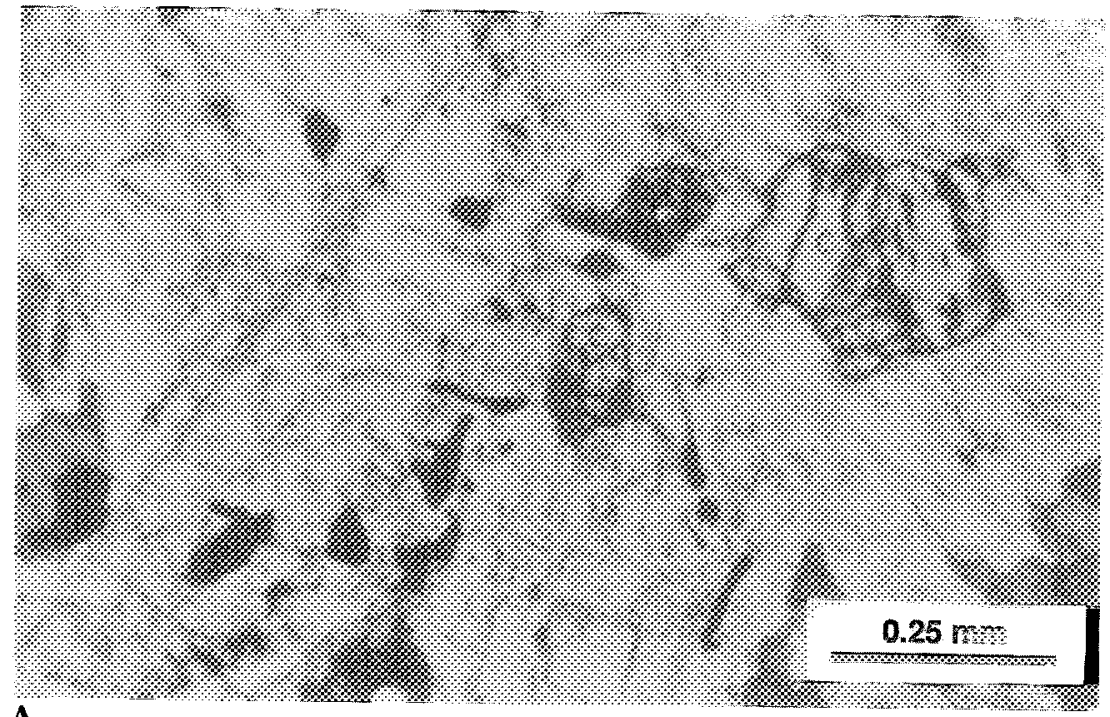

A
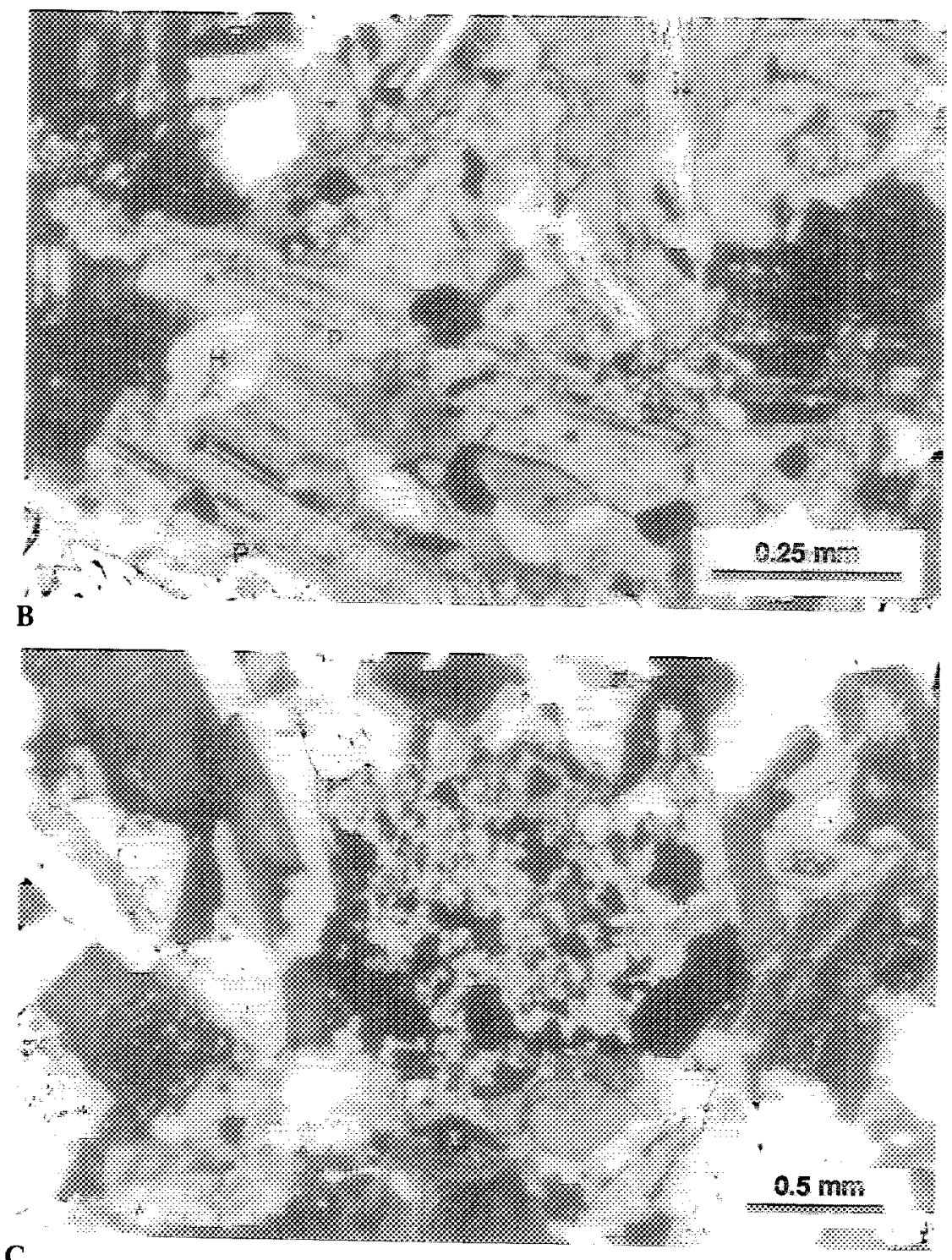


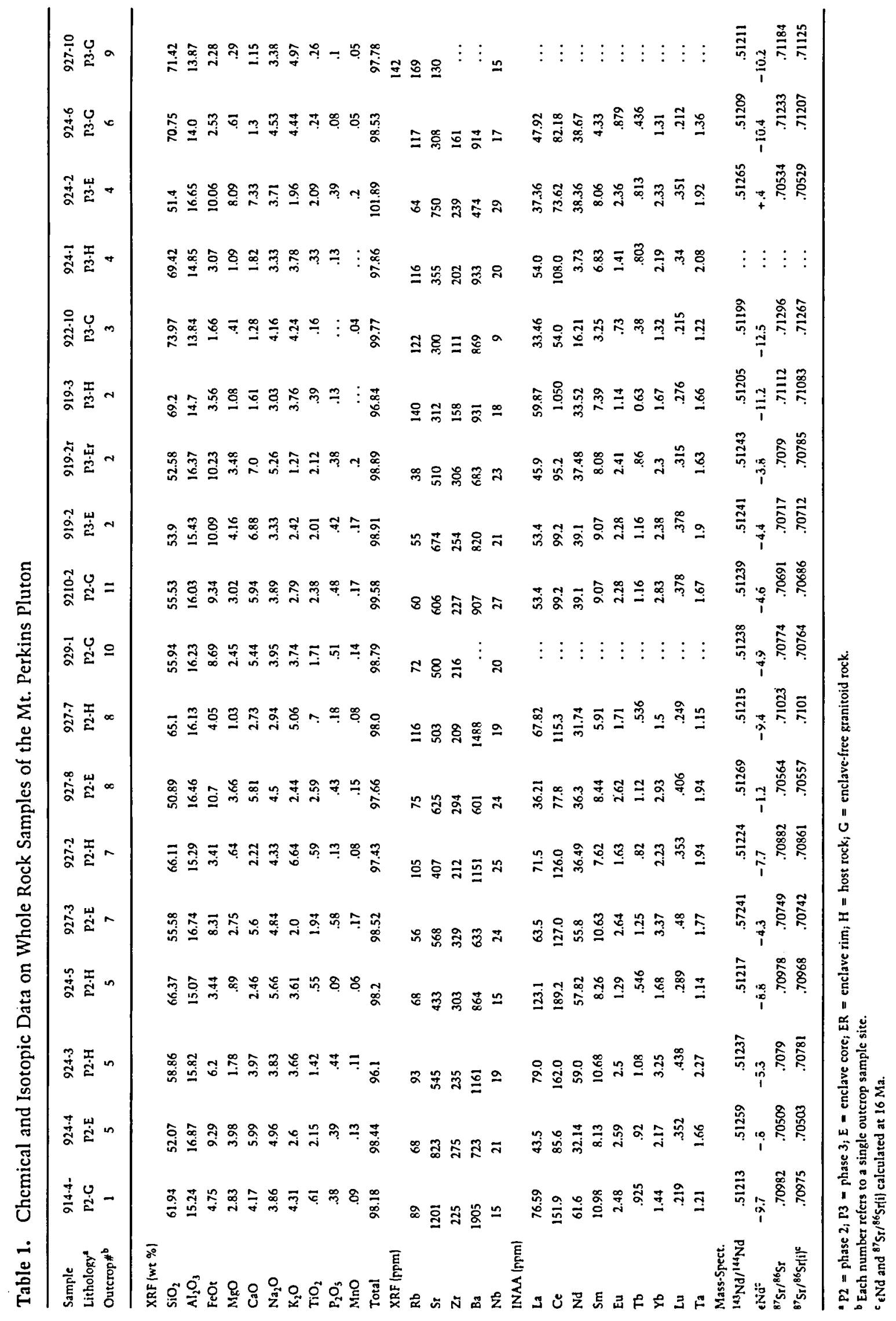


Figure 4. Major element harker variation diagrams. All concentrations are in weight percent.
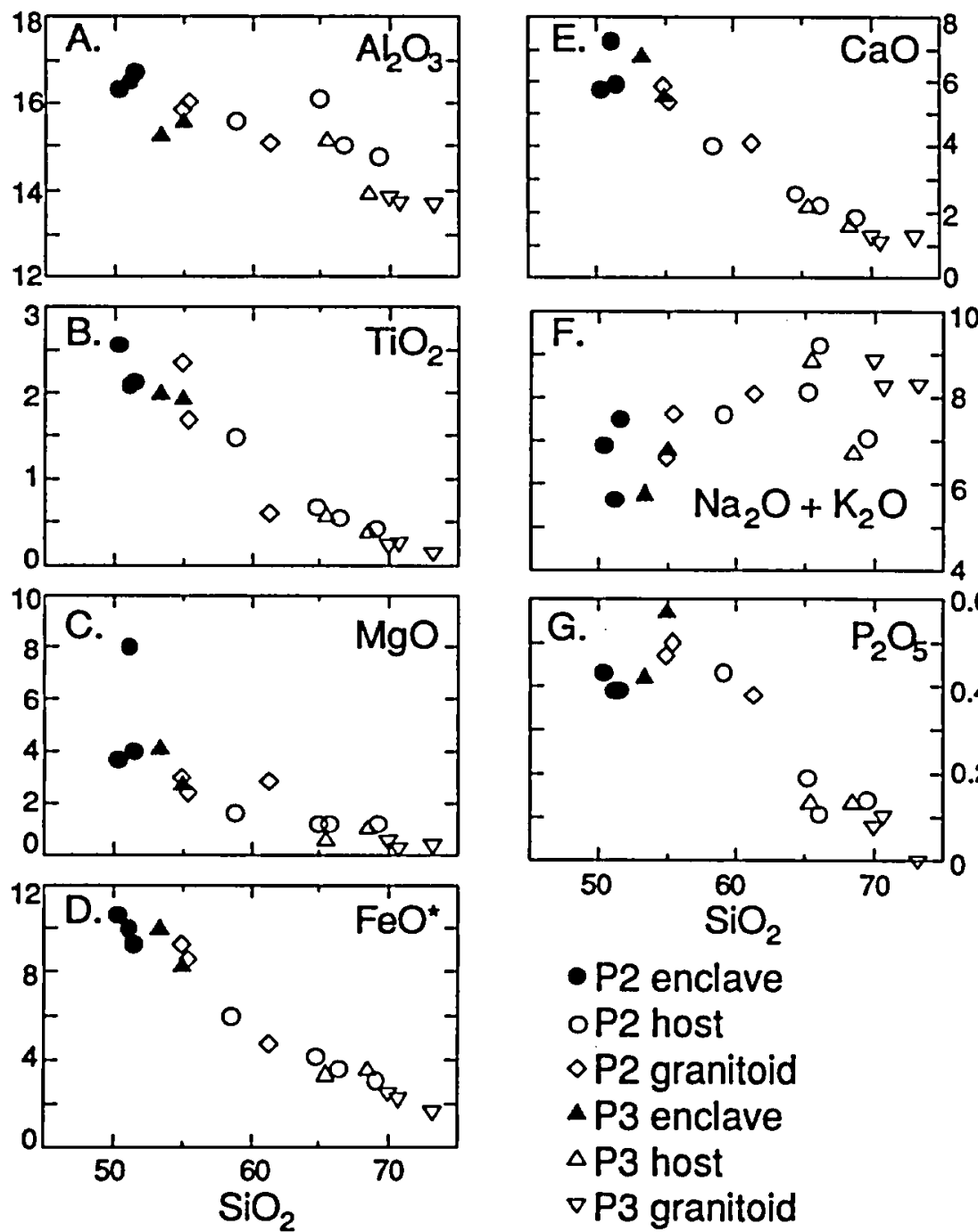

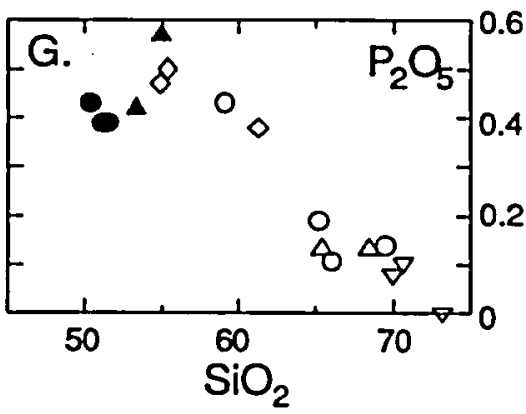

- P2 enclave

oP2 host

$\diamond \mathrm{P} 2$ granitoid

$\triangle P 3$ enclave

$\triangle P 3$ host

$\nabla P 3$ granitoid sampling and crushing of the host rock, larger centimeter-scale micro-enclaves were avoided; however whole rock analyses of these rocks include millimeter scale micro-enclaves. The five enclave samples were taken from enclave interiors, well away from fine-grained rims. For one of the enclaves, a fine-grained rim was analyzed in addition to the enclave interior. The isotope suite includes four enclave host rock sample sets, the enclave interior-rim pair, and six enclave-free granitoid samples.

Results. Enclaves, their enclosing host rocks, and the enclave-free granitoid rocks collectively form a continuous mafic to felsic calc-alkaline suite $\left(\mathrm{SiO}_{2}\right.$ range of 50 to $\left.74 \mathrm{wt} \%\right)$ and exhibit a covariance among major elements, trace elements, and $\mathrm{Nd}$ and $\mathrm{Sr}$ isotopes (table 1, figures 4, 5, and 6). As discussed later, these rocks represent a cogenetic suite. Phase 2 and 3 enclaves are distinctly more mafic $\left\{\mathrm{SiO}_{2}\right.$ 50-55 wt \%; $\mathrm{MgO} 8-3.6$ wt \%;
$\mathrm{CaO} 7.3-5.8 \mathrm{wt} \%)$ than enclosing intermediate to felsic granitoid host rocks $\left(\mathrm{SiO}_{2} 58-73 \mathrm{wt} \% ; \mathrm{MgO}\right.$ 1.8-0.3 wt \%; $\mathrm{CaO} 3.9-1.1 \mathrm{wt} \%$ ). Compositional overlap exists among phase 2 and 3 enclaves and the most mafic enclave-free granitoid rocks in phase 2 (figures 4 and 5). The entire suite shows decreases in $\mathrm{CaO}, \mathrm{MgO}, \mathrm{FeO}^{*}, \mathrm{Al}_{2} \mathrm{O}_{3}$, and $\mathrm{TiO}_{2}$ (figure $4 a-e$ ) with increasing $\mathrm{SiO}_{2} ; \mathrm{P}_{2} \mathrm{O}_{5}$ increases in the 50 to $55 \mathrm{wt} \% \mathrm{SiO}_{2}$ range (the enclave portion of the trend), then decreases with increasing $\mathrm{SiO}_{2}$ in a linear fashion (figure 4g). The suite exhibits linear trends of decreasing $\mathrm{Sr}$ and increasing $\mathrm{Rb}$ with increasing $\mathrm{SiO}_{2}$ (figure $5 a, b$ ). An inflection point at about 58 wt $\% \mathrm{SiO}_{2}$ occurs on LREE and $\mathrm{Ba}$ plots; these trace elements increase with increasing $\mathrm{SiO}_{2}$ below the inflection and decrease with increasing $\mathrm{SiO}_{2}$ above the inflection (figure $5 c-f)$. Eu shows the same inflection, but the distribution is nearly flat between 50 and 58 wt $\% \mathrm{SiO}_{2}$ (figure $5 \mathrm{~g}$ ). The HREE exhibit similar patterns as 

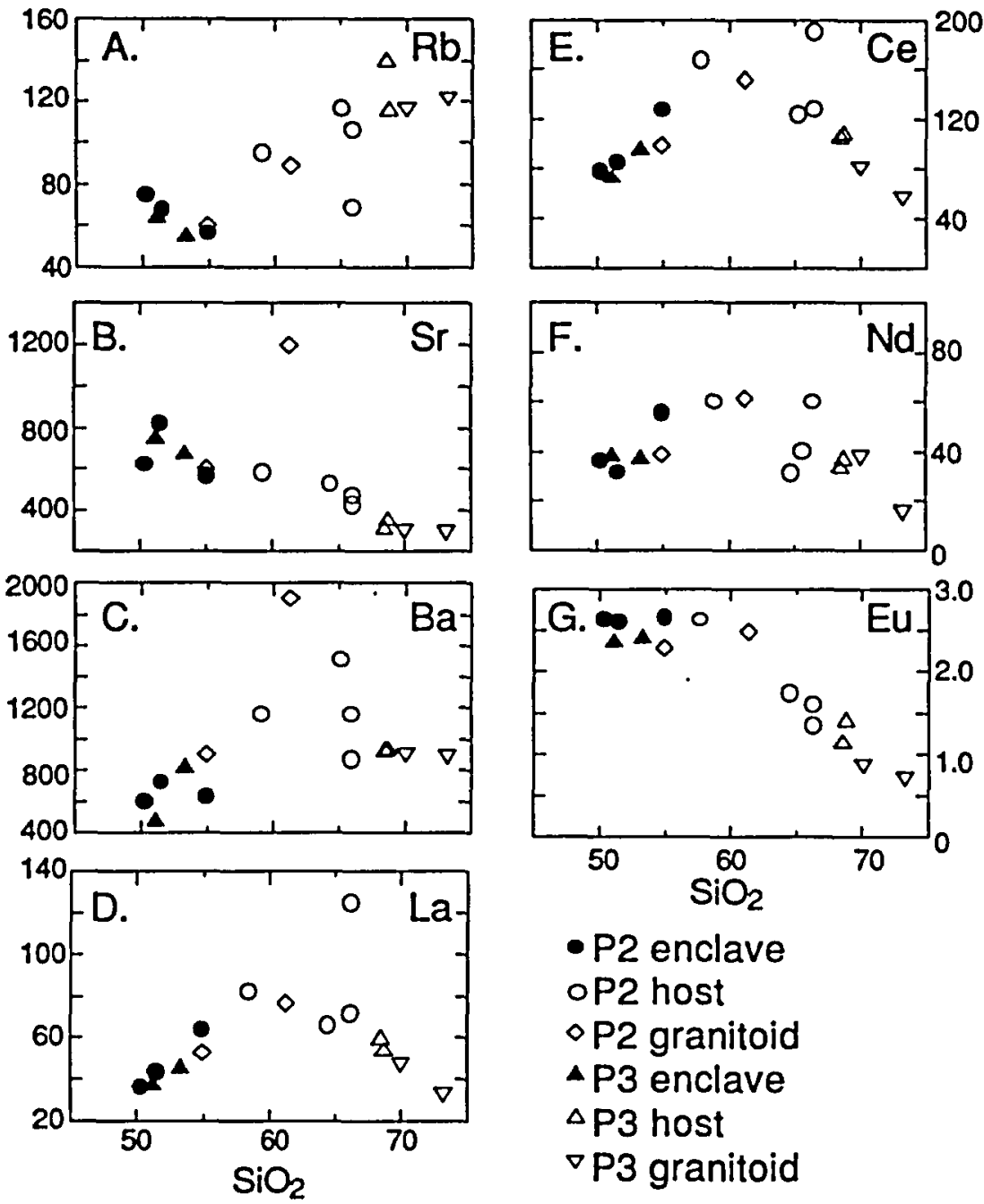

Figure 5. Trace element harker variation diagrams. Trace element concentrations are in parts per million and $\mathrm{SiO}_{2}$ concentration in weight percent. the LREE but with considerably more scatter. Epsilon $\mathrm{Nd}$ ranges from +1.2 to -12.5 and initial ${ }^{87} \mathrm{Sr} /$ ${ }^{86} \mathrm{Sr}_{\mathrm{Sr}_{\mathrm{i}}}$ ranges from 0.705 to 0.71267 within the suite (figure 6; table 1). Epsilon Nd shows a nega. tive correlation with $\mathrm{SiO}_{2}$ (figure $6 b$ ) and $\mathrm{Sr}_{\mathrm{i}}$ shows a positive correlation with $\mathrm{SiO}_{2}$ (figure $6 a$ ).

Large $\epsilon_{\mathrm{Nd}}$ and $\mathrm{Sr}_{\mathrm{i}}$ isotopic differences are preserved between enclave cores and their enclosing granitoid host rocks 16.8 to $10.6 \epsilon_{\mathrm{Nd}}$ units; 0.0036 to $0.0046 \mathrm{Sr}_{\mathrm{i}}$ units). These differences are illustrated in figure 7 where data for contiguous enclaves and host rocks are connected by tie-lines. In one outcrop (\#5, table 1), a single mafic enclave (sample 924-4: $\mathrm{SiO}_{2}=51.5 \mathrm{wt} \% ; \epsilon_{\mathrm{Nd}}=-0.8 ; \mathrm{Sr}_{\mathrm{i}}=0.7051$ with a crenulate margin touches two isotopically distinct host rocks, one intermediate in composition (sample 924-3: $\mathrm{SiO}_{2}=58.2 \mathrm{wt} \% ; \epsilon_{\mathrm{Nd}}=-5.3$; $\mathrm{Sr}_{\mathrm{i}}=0.70781 /$ and one more felsic in composition (sample 924-5: $\mathrm{SiO}_{2}=65.7 \mathrm{wt} \% ; \epsilon_{\mathrm{Nd}}=-8.8 ; \mathrm{Sr}_{\mathrm{i}}$ $=0.70968$ ) (figure 7).

The chemical composition of one enclave rim (sample $919-2 \mathrm{r}$ ) is compared with that of the enclave core (samples $919-2 c$ ) in figure 8 (see also table 1). Most elements show only minor differences between the enclave rim and core (e.g., $\mathrm{FeO}, \mathrm{MgO}$, $\mathrm{CaO}$ in figure $8 a-c)$; however, the alkali elements show a considerable variation with the rim being depleted in $\mathrm{K}_{2} \mathrm{O}$ and enriched in $\mathrm{Na}_{2} \mathrm{O}$ relative to the core (figure $8 d, e$ ). The rim has higher $\mathrm{Sr}_{\mathrm{i}} \mathrm{com}$ pared to the core, but core and $\operatorname{rim} \epsilon_{\mathrm{Nd}}$ values are similar (figure $8 f, h$ ).

\section{Problems in Interpreting Isotopic Data in Commingled Rocks.}

Neodymium and $\mathrm{Sr}$ isotope data from commingled rocks are often difficult to interpret. For example, the most mafic enclaves $\left(\sim 50 \mathrm{wt} \% \mathrm{SiO}_{2}\right)$ within a plutonic suite typically show moderately negative $\epsilon_{\mathrm{Nd}}$ and initial ${ }^{87} \mathrm{Sr} /{ }^{86} \mathrm{Sr}\left(\mathrm{Sr}_{\mathrm{i}}\right)$ above 0.706 (Dodge and Kistler 1990; Pin et al. 1990; Allen 1991; Holden et al. 1991). Such values are equally consis- 
Figure 6. Neodymium and $\mathrm{Sr}$ isotope plots: $(a)$ initial ${ }^{87} \mathrm{Sr} /{ }^{86} \mathrm{Sr}$ vs $\mathrm{SiO}_{2} \mid$ wt $\left.\%\right)_{;}(b)$ epsilon $\mathrm{Nd}$ vs. $\mathrm{SiO}_{2}$ (wt \%); $(c)$ epsilon $\mathrm{Nd}$ vs. initial ${ }^{87} \mathrm{Sr} /{ }^{86} \mathrm{Sr}$; fields for asthenospheric and enriched lithospheric mantle from Feuerbach et al (1993) and for crust from DePaolo and Wasserburg (1979) and Bennett and DePaolo (1987).
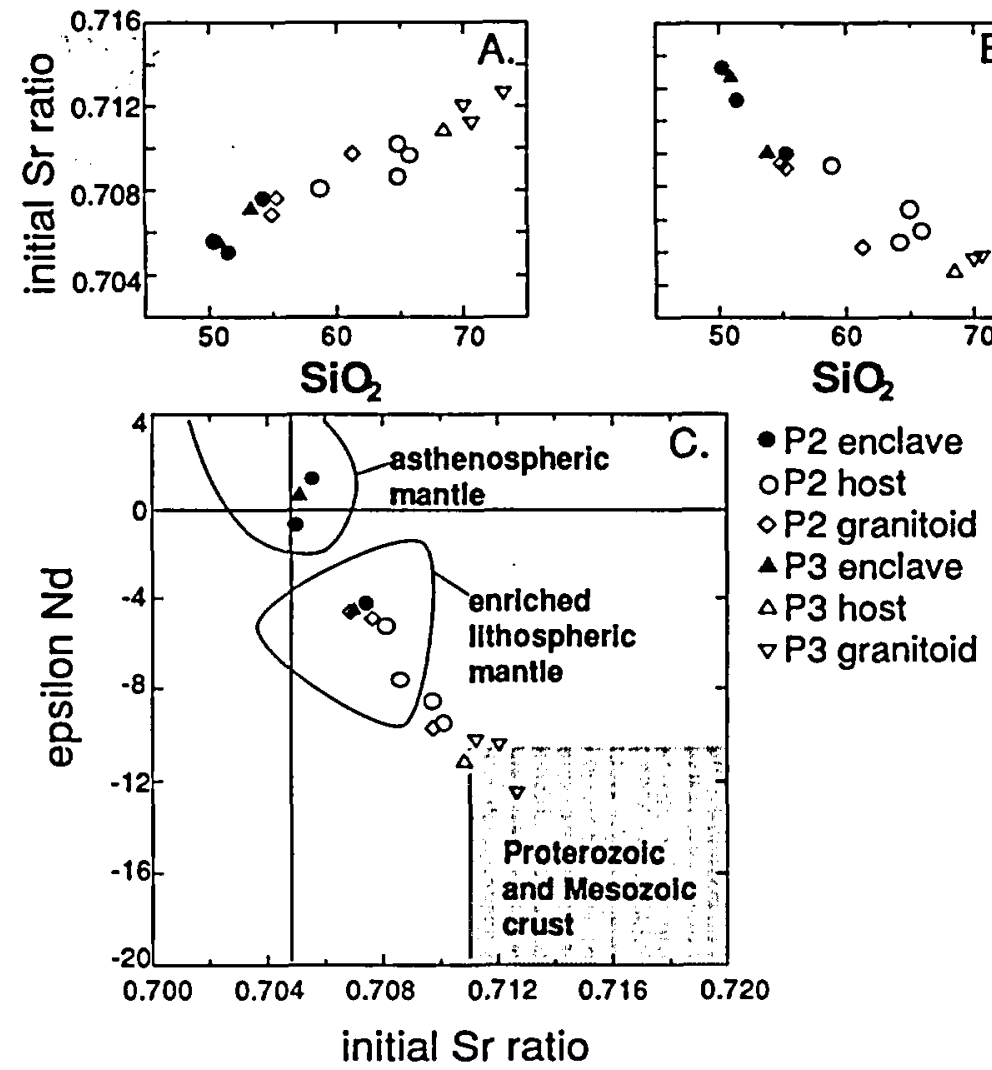

tent with melting of enriched lithospheric mantle, melting of asthenospheric mantle with subsequent crustal contamination, or perhaps even melting of mafic crust. In addition, most commingled plutonic suites exhibit a narrow overall range of isotopic values; variations $>4 \epsilon_{\mathrm{Nd}}$ units and $0.002 \mathrm{Sr}_{\mathrm{i}}$ units are rarely observed (Dodge and Kistler 1990; Pin et al. 1990; Holden et al. 1991). Enclaves and enclosing granitoid host rocks often exhibit little or no isotopic differences at the mesoscale. Such isotopic data may record commingling of isotopically similar magmas related to a common mafic parental magma via fractional crystallization, with or without small amounts of crustal assimilation. These magmas may commingle as they ascend from the site of fractional crystallization/assimilation at depth. This process has been referred to as the autolith model (Dodge and Kistler 1990; Barbarin and Didier 1992). Dodge and Kistler (1990) have used an autolith model to explain isotopic data from commingled rocks in the Sierra Nevada Batholith.

The narrow range of isotopic data used to support the autolith model may instead be due to considerable isotopic exchange after commingling of isotopically distinct magmas (Pin et al. 1990; Allen 1991; Holden et al. 1991). Experimental studies
(Baker 1989; Lesher 1990, 1994) have demonstrated that isotopic diffusion is much faster than chemical diffusion. In many plutonic environments (i.e., large, slowly cooled bodies/ rapid isotopic diffusion in commingled magmas may approach or even achieve local isotopic equilibrium, although significant chemical differences are preserved (e.g., Barbarin 1991; Fourcade and Javoy 1991; Pin 1991). In addition, Lesher $(1990,1994)$ showed that $\mathrm{Sr}$ isotopes have faster diffusion rates than $\mathrm{Nd}$ isotopes. Several studies described contiguous enclaves and host rocks with nearly identical $\mathrm{Sr}_{\mathrm{i}}$ but significantly different $\epsilon_{\mathrm{Nd}}$ (Holden et al. 1991; Allen 1991), suggesting complete equilibration of $\mathrm{Sr}$ isotopes but only partial isotopic equilibration of $\mathrm{Nd}$ isotopes. It is thus possible for isotopic exchange to obliterate mesoscale enclave-host isotopic differences among isotopically distinct commingled mafic and felsic magmas. Several workers advocate mixing of mantle-derived mafic magma and crustal-derived felsic magma to produce intermediate calc-alkaline magma suites in both extensional (Glazner 1990; Turner and Glazner 1991; Larsen and Smith 1991; Falkner et al. 1995/ and contractional (Fleck 1990; Foster and Hyndman 1990; Holden et al. 1991) tectonic settings. A number of workers have suggested such an origin for various 

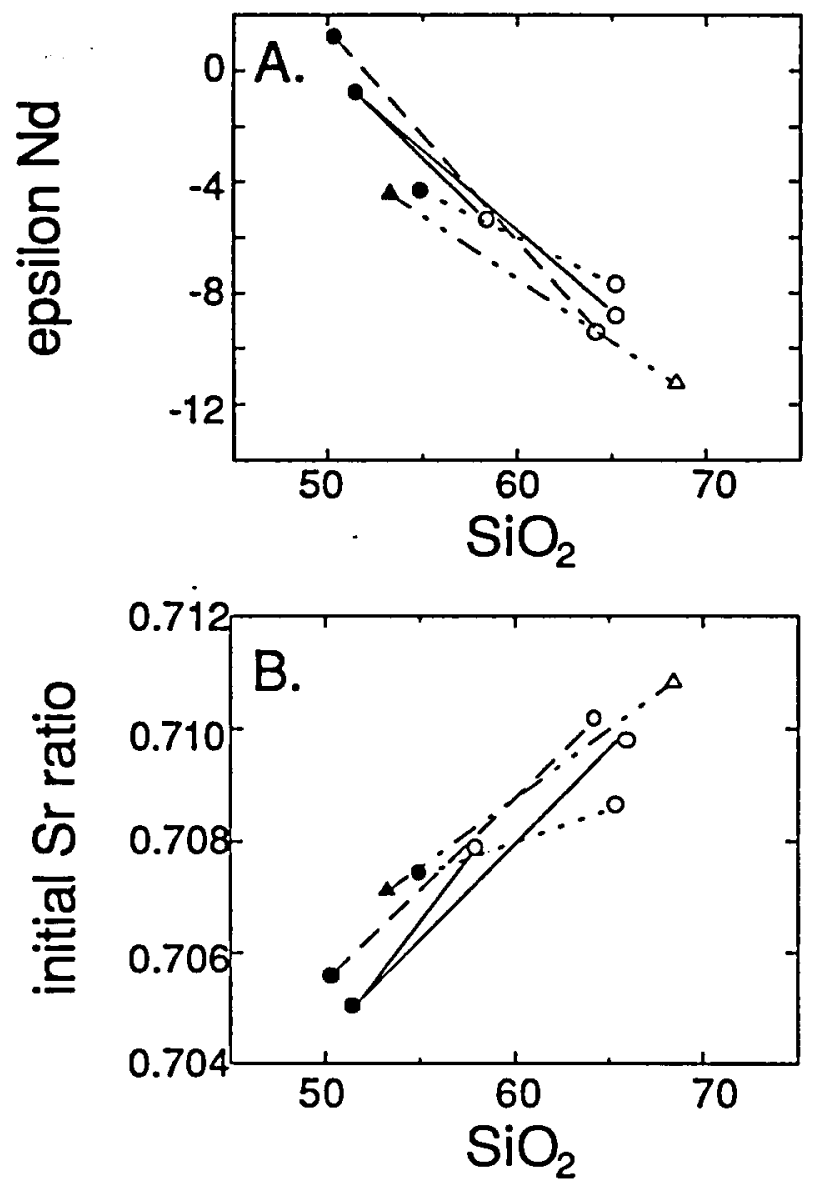

Figure 7. Isotopic disequilibrium between enclaves and enclosing host rocks. Solid symbols are enclaves, open symbols are host rocks, circles are phase 2 samples, triangles are phase 3 samples. Tie-lines connect enclaves and host rocks from the same outcrop. One enclave is connected to two host rock data points and represents an outcrop where a single enclave is in contact with two host rock compositions: (a) Epsilon $\mathrm{Nd}$ vs. $\mathrm{SiO}_{2}$ (wt \%); and $(b)$ initial ${ }^{87} \mathrm{Sr} /{ }^{86} \mathrm{Sr}$ vs. $\mathrm{SiO}_{2}$ (wt $\%$ ).

portions of the Sierra Nevada batholith (Reid et al. 1983; Furman and Spera 1985; Bateman 1989; Dorais et al. 1990; Barbarin 1991).

\section{Incipient Commingling and Enclave-Host Isotopic Disequilibrium}

Several lines of evidence demonstrate that the Mt. Perkins enclaves originated as globules of hotter mafic magma quenched within cooler, more felsic host magma. These include (1) the widespread preservation of enclaves with fine-grained, crenulate margins (figure $2 c) ;(2)$ the presence of igneous microstructures, in particular euhedral plagioclase and hornblende (figure $3 b$ ); and $(3)$ the presence of acicular apatite (figure $3 a$ ), which is considered evi- dence of rapid undercooling (Wyllie et al. 1962). Largely absent in the Mt. Perkins pluton are features indicative of more advanced mechanical mixing, such as the mafic schlieren, disrupted mafic dikes, and abundant magmatic flow structures as seen in other plutonic bodies (e.g., Lamark granodiorite, Frost and Mahood 1987; Wilson Ridge pluton, Larsen and Smith 1991; Lago della Vacca suite, John and Blundy 1993). The lack of advanced mixing features was likely the result of rapid cooling and crystallization immediately following magma commingling. Rapid cooling resulted from the pluton's small size and the low temperature of the country rock related to a shallow emplacement level. Country rock temperature at the time of emplacement is estimated to have been approximately $240^{\circ} \mathrm{C}$, based on $15^{\circ} \mathrm{C}$ at the surface, a depth of $7.5 \mathrm{~km}$, and a reasonably high geothermal gradient of $30^{\circ} \mathrm{C} / \mathrm{km}$. The protracted emplacement history (discussed previously), which indicates that only a portion of the small pluton was in a magmatic state at a given time, also was a factor in the rapid cooling of the $\mathrm{Mt}$. Perkins magmas.

Outcrop-scale chemical (figures 4 and 5) and $\mathrm{Nd}$ and $\mathrm{Sr}$ isotopic (figure 7) differences between enclaves and host rocks record a state of compositional disequilibrium. This presumably results from the commingling of chemically and isotopically distinct magmas; one outcrop (\#5, see table 1) appears to record the commingling of three chemically and isotopically distinct magmas (figure 7). The preservation of disequilibrium compositions resulted from a lack of chemical and isotopic diffusion between liquids within the commingled magmas. Chemical disequilibrium among enclaves and host rocks is common lotherwise enclaves would be unrecognizable) owing to the relatively slow diffusion rates for most elcments. Isotopic disequilibrium, on the other hand, is relatively rare and merits further discussion.

Given its high rate, isotope diffusion in the Mt. Perkins rocks must have been arrested almost immediately upon commingling. There are two probable contributing factors. First, the development of chilled margins on many enclaves may have acted as a diffusion barrier between the commingled magmas. Second, the rapid and complete crystallization of one or both of the commingled magmas may have arrested the diffusion process. In the case of commingling of magmas with large differences in initial temperatures (i.e., magmas at each end of the mafic-felsic spectrum) and a low ratio of mafic-to-felsic magma, the hotter mafic magma would have been completely crystallized by thermal equilibration between enclave and host 
Figure 8. Composition of a phase 3 enclave core (sample 919-2) with its rim (fine-grained chilled margin, sample 919-2r). Also shown are the compositions of the host granite (labeled proximal host, sample 919-3) and a granite from the enclave-free phase 3 llabeled distal granitoid, sample 922-10). Samples 919-2, 919-2r, and $919-3$ are from a single outcrop; sample $922-10$ is from elsewhere in the pluton and shown for comparison. $(a)-(g)$ horizontal axis represents relative position; oxide concentrations are in weight percent.

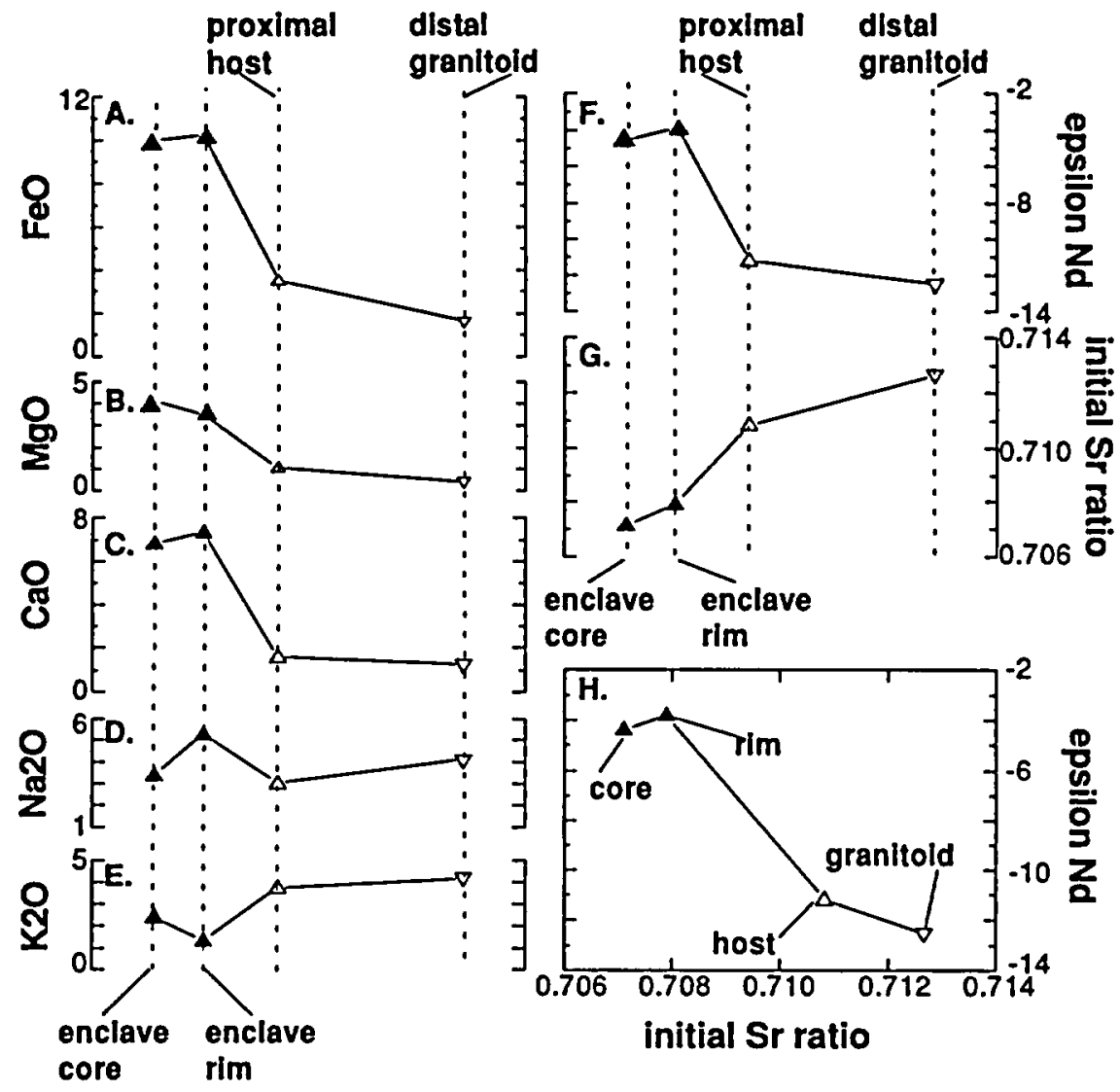

(Sparks and Marshall 1986). However, smaller compositional differences are recorded in some of the enclave-host pairs; particularly in phase 2 , suggesting only small temperature differences. In addition, the proportion of mafic to felsic rocks is rather high in many outcrops (up to 0.7 ). Consequently, crystallization of both magmas due to rapid heat loss to the surrounding country rock was probably an important factor in preventing isotopic exchange.

The perservation of enclave-host chemical and isotopic disequilibrium features does not, by itself, demonstrate a complete lack of in situ magma modification. Our data suggest that, although some in situ modifications did occur, both their scale and magnitude were small. Comparison of the one enclave core-rim pair (figure 8 ) indicates that chemical and isotopic modification occurred within the chilled margin of the enclave (rim). This modification was limited, however, to components known from experimental studies to have high diffusion rates, i.e., alkali elements (Watson and Jurewicz 1984; Baker 1990) and Sr isotopes (Lesher $1990,1994)$. It is noteworthy that the chilled margin shows evidence of $\mathrm{Sr}$ isotope exchange with the enclosing felsic host whereas little $\mathrm{Nd}$ isotopic exchange is indicated figure $8 f-g)$. The situation is identical to that produced by isotopic decoupling in short-duration diffusion experiments 11.5-12 hrs at $1465^{\circ} \mathrm{C}$; Lesher 1990,1994$)$. Microenclaves in some phase 2 and 3 hosts (figures $2 c, 3 c$ ) apparently represent droplets of mafic magma mechanically entrained within host magmas during the commingling event. The small in situ chemical and isotopic compositional shift of host magma produced by micro-entrainment can be estimated by comparing granites from enclave-rich and enclave-free portions of phase 3 lopen triangles and inverted open triangles, respectively, in figures 3 , 4 , and 5).

We conclude that the Mt. Perkins pluton records an incipient state of magma commingling. A lack of disnupted mafic dike structures within hosts or trains of enclaves with dike-like geometry suggests that commingling occurred during emplacement of phases 2 and 3 rather than by injection of mafic magma into more felsic magma already in residence within the Mt. Perkins pluton. Immediately upon commingling, rapid cooling and crystallization prevented both significant mechanical stirring of the magmas and chemical and isotopic diffusion between the magmas. At the current exposure 
level, magma hybridization in the host magmas was restricted to the entrainment of microen. claves, while hybridization of enclave magmas was restricted to diffusion at the rims and then primarily to components with high diffusion rates. In essence, the Mt. Perkins pluton represents a fossil state of chemical and isotopic disequilibrium among a suite of commingled magmas.

\section{Origin of Compositional Variation within the Mt. Perkins Suite}

Despite our conclusion that magma interactions within the Mt. Perkins pluton were limited to mechanical commingling with almost no compositional modification or hybridization, the compositional continuum exhibited collectively by enclaves, host rocks, and enclave-free granitoid rocks, combined with the clear compositional covariations seen in figures 4,5 , and 6 , strongly suggest that phase 2 and 3 rocks represent a single cogenetic suite. Furthermore, the process(es) that produced this suite must have operated in a subjacent magma chamber and prior to the commin. gling events that produced the $\mathrm{Mt}$. Perkins pluton. Major element, trace element, and isotopic modeling techniques can be used to evaluate the petrogenetic process(es) responsible for these compositional variations.

Isotopic variation within the Mt. Perkins suite indicates the importance of open-system processes (i.e., assimilation or magma mixing) in the evolution of the Mt. Perkins magmas. Inflections in LREE and $\mathrm{Ba}$ data (figure 5) suggest a component of fractional crystallization in magma evolution. Furthermore, these inflections indicate a two-stage evolution with stage-one magmas having 50 to 58 wt $\% \mathrm{SiO}_{2}$ and stage-two magmas with $>58 \mathrm{wt} \%$ $\mathrm{SiO}_{2}$. From the standpoint of numerical modeling, assimilation and magma mixing are identical processes, except for the material selected to represent the felsic contaminant. The presence of Miocene plutons within the NCREC exhibiting more advanced stages of magma mixing (i.e., Wilson Ridge pluton, Larsen and Smith 1991; Aztec Wash pluton, Falkner et al. 1995/ favors magma mixing rather than assimilation as the major open-system process in the Mt. Perkins suite.

We used open-system models including combined fractional crystallization and magma mixing as well as simple magma mixing to evaluate magma evolution within the Mt. Perkins suite. Major element models were developed using the XLFRAC program (Stormer and Nicholls 1978), which employs a least squares mass-balance tech-
Table 2. Liquid-Crystal Trace Element Distribution Coefficients Used in Stage-One Models

\begin{tabular}{llllllll}
\hline & $\mathrm{La}$ & $\mathrm{Ce}$ & $\mathrm{Nd}$ & $\mathrm{Sm}$ & $\mathrm{Eu}$ & $\mathrm{Sr}$ & $\mathrm{Ba}$ \\
\hline Plagioclase & .109 & .085 & .084 & .065 & .066 & 1.8 & .23 \\
Hornblende & .156 & .2 & .33 & .52 & .59 & .4 & .6 \\
Magnetite & .02 & .032 & .038 & .053 & .055 & .01 & .01 \\
\hline
\end{tabular}

Source. From Arth and Hanson (1975) and Drake and Weill (1975).

nique to determine the proportions of phases to be added and/or subtracted to produce a hybrid magma from a particular parent magma. Mineral compositions used in the models were either taken from the literature (opaque oxide minerals, Deer et al. 1972) or based on microprobe data collected from the phase 1 gabbro and phase 2 mafic enclaves (R. Metcalf, 1995). Open-system trace element and isotope models employed both the DePaolo AFC equations (DePaolo 1981) and simple mixing equations (Wilson 1989, p. 92). Major element models were used to constrain the trace element and isotope models (i.e., fractionating minerals and their proportions, rate of fractionation to mixing). Published crystal/liquid distribution coefficients for rocks of appropriate composition (basalticandesite) were used in the AFC portion of the trace element models (table 2).

Stage-one models used a mafic enclave (sample $927-8$ ) as the mafic parental magma. In both stageone and stage-two models an enclave-free phase 3 granite (sample 922-10) was used as the felsic mix: ing end-member. We tested a variety of stage-one models using various combinations of olivine, augite, plagioclase (both $A n_{70}$ and $A n_{50}$ ), hornblende, biotite, magnetite, ilmenite, apatite, and titanite as potential fractionating phases. The best-fit stage-one major element model (the sum of the squares of the residuals $[R]$ is 1.5) involved production of an intermediate magma (quartz diorite sam. ple $927-3,58.9$ wt $\% \mathrm{SiO}_{2}$ | by fractionation from the mafic parental magma of $2.5 \%$ plagioclase $\left(A n_{50}\right), 11.9 \%$ hornblende and $2.3 \%$ Fe-oxide plus the addition of $42 \%$ felsic magma (table 3, model A). This model produces an $r$-value (ratio of mass $\mathrm{mixed} / \mathrm{mass}$ fractionated) of 2.5 , which is prohibitively high when applied to the trace element and isotope models. A reasonable fractional crystallization (without mixing) major element model (model $\mathrm{B}$ in table 3 ) was calculated using the same three minerals $(R=3.26 ; 18.4 \%$ plagioclase; $21.7 \%$ hornblende; $5.3 \%$ Fe-oxide). We used major element models $A$ and $B$ to constrain stage-one trace element and isotope models. The preferred stage- 
Table 3. State-One Petrogenetic Models

\begin{tabular}{lccc}
\hline & Model A & Model B & Model Cc \\
\hline Hornblende & -11.9 & -21.7 & -13.4 \\
Plagioclase & -2.5 & -18.4 & -4.4 \\
Magnctite & -2.3 & -5.3 & -2.9 \\
Granite & +42 & $\ldots .26$ & +18 \\
$\mathrm{R}^{\mathrm{d}}$ & 1.5 & 3.26 &. .9 \\
$r^{\mathrm{c}}$ & 2.5 & $\ldots$. & .86 \\
$X_{\text {mafic }}{ }^{\mathrm{b}}$ & .5 & $\ldots$ & .8 \\
\hline
\end{tabular}

Note. Negative numbers are amounts removed; positive numbers are amounts added.

a Fractional crystallization/mixing model calculated from major element data using XLFRAC program (Stormer and Nicholls 1978).

${ }^{b}$ Fractional crystallization model calculated from major element data using XLFRAC program.

c Preferred trace element and isotope model interpolated from models $A$ and $B$.

d Square of the sum of the residuals calculated by XLFRAC.

e Ratio of mass added/mass removed for open system models A and $\mathrm{C}$.

Mass fraction of mafic magma in hybrid magma.

one trace element and isotope model (model $\mathrm{C}$ in table 3 ) produces an intermediate magma by fractionation of $4.4 \%$ plagioclase, $13.4 \%$ hornblende and $2.4 \%$ Fe-oxide from the mafic parental magma and the addition of $18 \%$ felsic magma $(r=0.9)$. This stage-one trace element and isotope model is illustrated by solid lines in figure 9 .

A reasonable open-system major element model for stage two $(R=4.71)$ produced sample 927-2 166 wt $\% \cdot \mathrm{SiO}_{2}$ / by the fractionation of $7.2 \%$ plagioclase $\left\langle\mathrm{An}_{50}\right|$ and $10 \%$ biotite from an intermediate magma (sample $927-3 ; 58.9$ wt $\% \mathrm{SiO}_{2}$ ) with the addition of $43.2 \%$ felsic end-member magma $\mid r=$ 2.5). Trace element and isotope models calculated by application of these results did not fit the observed data, even allowing for considerable variation of the input variables and the addition of small amounts of accessory apatite and titanite to the fractionating assemblage. A stage-two model involving magma mixing only provides the best fit with observed data and is illustrated by a series of mixing lines in figure 9. Three mixing lines are shown, each represents mixing of the felsic contaminant magma with one of three different intermediate stage-one model hybrid magmas.

The two-stage model provides a reasonably good fit with the observed data. Even for data that shows some scatter (figure $9 c, e, f, g$ ), the model curves closely approximate the data trends. Examination of figure 9 suggests that stage-two mixing began when $15 \%-25 \%$ of the parental magma had crystallized $(F=0.85-0.75$ in figure 9$)$. With a ratio of mass mixed/mass fractionated of 0.9 ( $r$ in table 3 ),
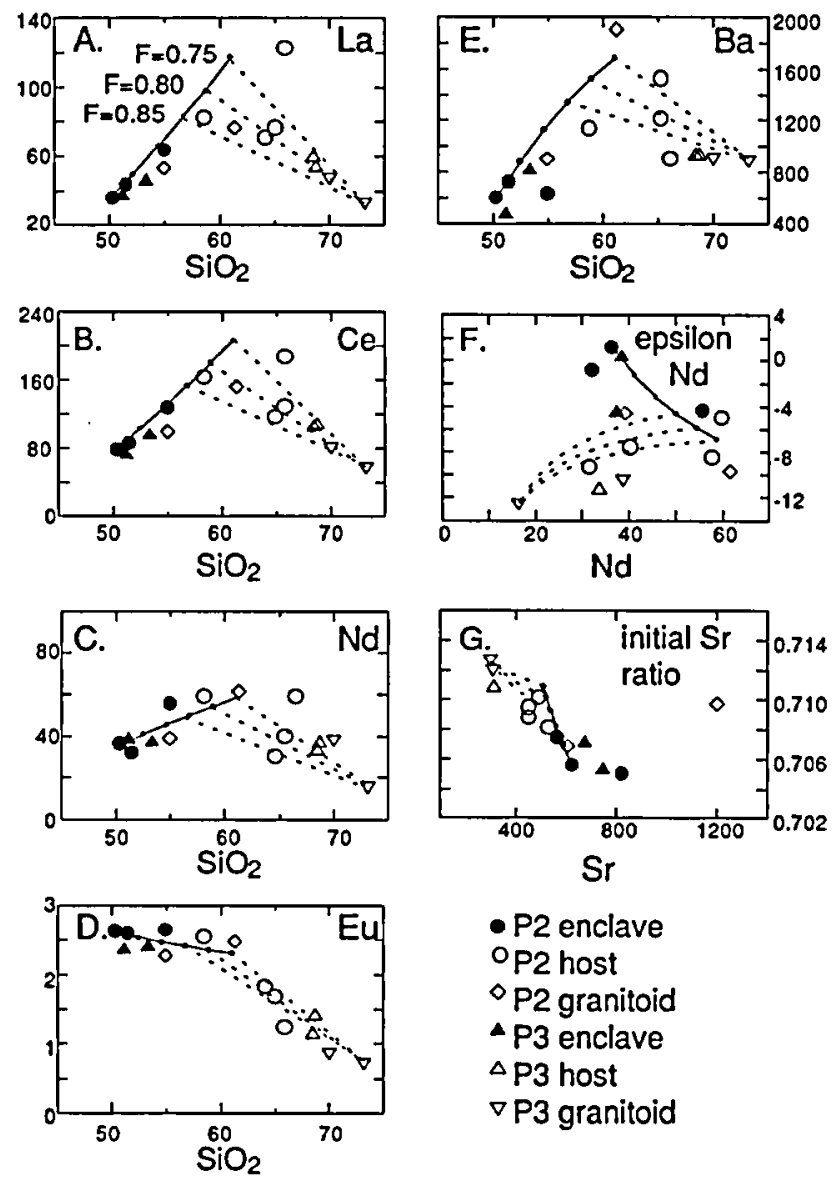

- P2 enclave

op2 host

-P2 granitoid

- P3 enclave

$\triangle P 3$ host

$\nabla$ P3 granitoid

Figure 9. Results of trace element and isotope modeling. The stage-one model, shown as solid lines, involves combined fractional crystallization and magma mixing according to model $\mathrm{C}$ in table 3 . Stage-one model curve was calculated using the DePaolo equations (DePaolo 1981). The fraction of original parental magma remaining $(F)$ is marked on the model curve in diagram (a) for $F=0.85,0.8,0.75$; all model curves are marked off in increments of $0.05 \mathrm{~F}$. The stage-two portion of the model is shown as a series of mixing lines (dashed lines). Each mixing line was calculated using the mixing equations in Wilson $(1989$, p. 92). In each diagram, three mixing lines are shown; each represents mixing of the felsic end-member magma with one of three stage-one hybrid magmas $(F=0.85,0.8,0.75)$.

the final stage-one hybrid magma contained a mafic magma mass-fraction of between 0.86 and $0.77\left(X_{\text {mafic }}\right.$ in table 3$)$. The mass-fraction of stageone hybrid magma (stage-two mixing end-member) within stage-two hybrid magmas reached a maximum of about 0.5 .

\section{End-Member Magma Sources}

Trace element and isotope data constrain the source of the mafic and felsic end-member magmas 
in the Mt. Perkins suite. We used the two most mafic enclave samples and two samples of phase 3 enclave-free granite to represent the felsic and mafic end-member magmas, respectively. These samples were used as end-members in the petrogenetic models.

Mafic Magma Source. Using Fitton et al.'s (1991) approach in which mafic magmas $\left(<55\right.$ wt $\left.\% \mathrm{SiO}_{2}\right)$ are normalized to average oceanic island basalts (OIB) we evaluated incompatible trace elements. Although OIB may be derived by melting of mixed mantle components, including continental lithosphere recycled by subduction, their origin clearly lies within asthenosphere (Fitton et al. 1991). OIB thus serves as an "asthenospheric reference" (Fitton and Dunlop 1985; Menzies 1989). Within areas of continental extension, mafic parental magmas with trace element compositions that differ from OIB signify the involvement of crustal and/or mantle lithosphere. Basalts in southern Nevada (including the NCREC) thought to be derived from lithospheric mantle have low $\epsilon_{\mathrm{Nd}}(-3$ to -10$)$, high $\mathrm{Sr}_{\mathrm{i}}(>0.706)$ (figure $6 c$ ), are enriched in $\mathrm{Ba}$ and depleted in $\mathrm{Nb}$ and $\mathrm{Ti}$ compared to OIB (Farmer et al. 1989; Fitton et al. 1991; Feuerbach et al. 1993). Figure $10 a$ is an OIB-normalized plot of Mt. Perkins enclaves.

The most mafic $\mathrm{Mt}$. Perkins rocks are alkalic (i.e., $\mathrm{Na}_{2} \mathrm{O}+\mathrm{K}_{2} \mathrm{O}>\sim 4$ wt $\%$ at $\sim 50$ wt $\%$ in figure $4 f($ and have low overall trace element contents (figure 5 and table 1). Barium, Ta, LREE, Sr, P, $\mathrm{Zr}$, and $\mathrm{Ti}$ abundances are close to $\mathrm{OIB}, \mathrm{Nb}$ shows a small negative spike, and $\mathrm{Rb}$ and $\mathrm{K}$ show small positive spikes (figure 10a). The OIB normalized patterns (figure 10a) are very similar to Pliocene basalts from both the Lake Mead area (Feuerbach et al. 1993, figure $10 \mathrm{~b}$, page 1572) and the Colorado Plateau-Basin and Range transition zone (Fitton et al. 1991, figure 6, page 13,705 ) thought to be derived largely from the asthenosphere. The Mt. Perkins mafic rocks have less radiogenic $\mathrm{Sr}$ isotopic ratios and more radiogenic $\mathrm{Nd}$ isotopic ratios than southern Nevada lithospheric mantle and are similar to bulk earth values $\mid \epsilon_{N d}+0.4$ and $+1.2 ; \mathrm{Sr}_{\mathrm{i}}$ 0.70529 and 0.70557 ; figure $6 a$ l. We interpret these data to reflect a large component of asthenosphere in the source of the Mt. Perkins mafic endmember. At least two lines of evidence suggest that the mafic enclaves used here are not the primary mantle-derived mixing end-member: (1) collectively enclaves form a significant portion of stage-one mixing/fractionation lines (figures 3,4 and 5); and (2) the presence of resorbed clinopyroxene suggests crystal-liquid disequilibrium. These features indicate modifications by the stage-one
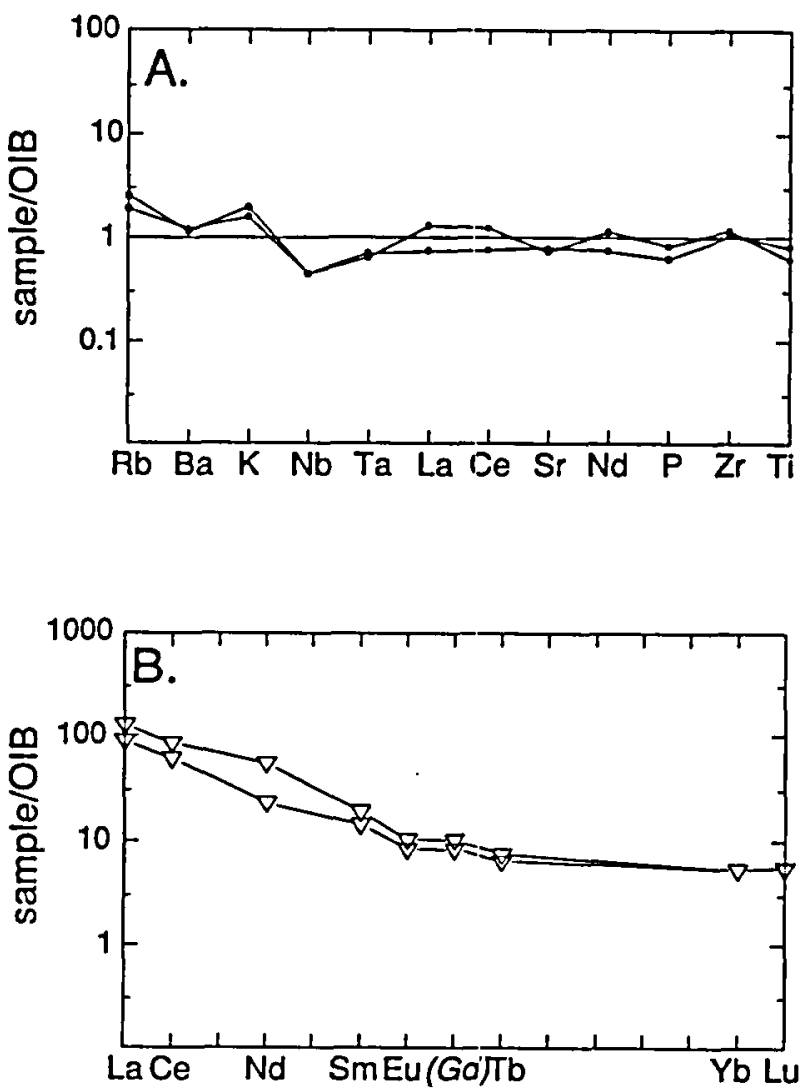

Figure 10. Normalized trace element plots of samples representative of $(a)$ the mafic end-member magma, and (b) the felsic mixing end-member. (a) Incompatible trace elements from enclave samples $924-2$ and $927-8$ are normalized to average ocean island basalt (OIB), normalizing values from Fitton et al. (1991) except Ta from Sun and McDonough (1989); (b) REE from enclave-free phase 3 granite samples 922-10 and 924-6 normalized to chondrite values, normalizing values from Sun and McDonough (1989).

mixing/fractionation processi discussed earlier; however, this modification appears to be insufficient to mask the asthenospheric signature of the magma source.

Felsic Magma Source. A U-I'b analysis of zircons from a phase 3 enclave-free granite (sample 927-6) reveals a major component of inherited Proterozoic zircon (discordia upper intercept at $1542 \pm 752$ Ma; Mark Martin, unpublished data) confirming the role of Proterozoic crust in production of the felsic end-member. A chondrite-normalized REE plot exhibits an LREE-enriched and a flat HREE pattern, suggesting residual clinopyroxene and/or amphibole in the source rocks (figure 10b). This favors a middle-to-lower crustal source. MidCenozoic magmas derived solely from continental crust (exmplified by exposed Mojave Proterozoic crust) should have $\epsilon_{\mathrm{Nd}}$ values of -15 or below (Ben- 
nett and DePaolo 1987) and $\mathrm{Sr}_{\mathrm{i}}$ values of about 0.72 (DePaolo and Wasserburg 1979). The Mt. Perkins granite, however, has slightly higher $\epsilon_{\mathrm{Nd}} \mid-10.2$ to $-12.5)$ and lower $\mathrm{Sr}_{\mathrm{i}}(0.71125$ to 0.71267$)$. The $\mathrm{Nd}$ and $\mathrm{Sr}$ isotope data may indicate a contribution of mantle-derived Mesozoic granitoid rock $\mid \epsilon_{\mathrm{Nd}} \sim$ $-11, \mathrm{Sr}_{1} \sim 0.711$, Miller and Wooden 1993) within the Proterozoic source region. This interpretation is similar to that of Falkner et al. (1995) for felsic rocks in the Miocene Aztec Wash pluton.

\section{Discussion}

The processes that produced the evolutionary trends in the Mt. Perkins suite (i.e., magma mixing and fractional crystallization) must have occurred within a magma chamber at depth. If commingling occurred during emplacement of the Mt. Perkins magmas, then the various compositions within each emplacement phase reflect compositional variability within the subjacent magma chamber at the time it was tapped. The chemistry of phases 2 and 3 , because they represent quenched magmas, can be used to evaluate processes operating in the magma chamber in a fashion similar to that commonly applied to volcanic rocks. A model for the subjacent magma chamber (figure 11) uses the Miocene Wilson Ridge pluton (Larsen and Smith 1991) and the Silurian Cadillac Mountain pluton (Seaman and Ramsey 1992; Weibe 1994) as analogs. The first stage in the model is the injection of asthenospheric mantle-derived mafic magma into the floor of an existing chamber of crustalderived felsic magma (step 1 in figure 11). The mafic magma undergoes fractional crystallization while mixing with small amounts of felsic magma (petrogenetic model, stage one). As the stage-one hybrid magma evolved toward intermediate compositions, its rheological contrast with the felsic magma decreased, and simple mixing of intermediate hybrid magma with felsic end-member magma became possible (petrogenetic model, stage two). By a combination of stage-one and stage-two processes, a layer of compositionally variable hybrid magma formed between the mafic and felsic endmember magmas (step 2 in figure 11). Emplacement phase 2 of the Mt. Perkins pluton formed by tapping primarily the zone of intermediate hybrid magmas in the subjacent chamber (step 3 in figure 11). The compositionally bimodal emplacement phase 3 tapped the unmodified felsic end-member magma and the more mafic portions of the hybrid zone (step 4 in figure 11). In summary, our model for the Mt. Perkins magma system involves two stages of open-system behavior: production of hy-
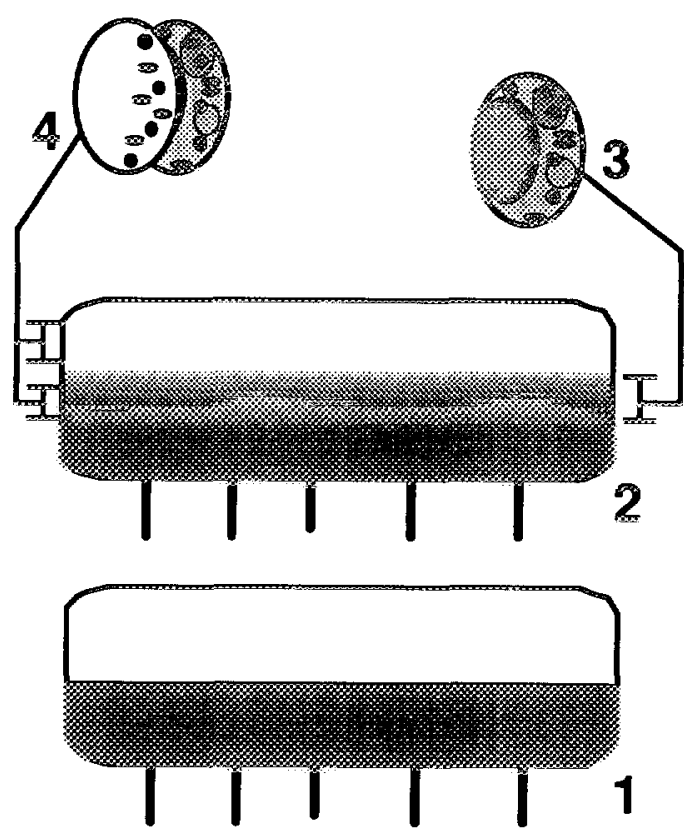

Figure 11. Schematic model showing magma evolution in a postulated magma chamber beneath the Mt. Perkins pluton. Step 1: mafic magma from the asthenospheric mantle intrudes into the base of a preexisting magma chamber filled with felsic magma derived by melting of continental crust. This chamber resided at an unknown depth beneath the Mt. Perkins pluton. Step 2: a layer of intermediate magmas forms between the mafic and felsic magma by fractional crystallization of the mafic magma combined with the mixing of felsic magma (see text for details of two-stage petrogenetic model). Step 3: intermediate hybrid magmas in the subjacent chamber were tapped and commingled as they ascended to be emplaced as phase 2 of the Mt. Perkins pluton. Step 4: intermediate hybrid magmas and unmodified felsic endmember magmas were tapped and commingled as they ascended to be emplaced as phase 3 of the Mt. Perkins pluton.

brid magmas by an early magma mixing/fractional crystallization event at depth, followed by commingling of these hybrid magmas upon ascent to a shallower crustal level. A similar model of multiple open-system magma evolution events at different levels of the crustal was proposed for the Sierra Nevada Batholith by Barbarin (1991).

The mass-fraction of mafic magma in the stageone hybrid rocks is 0.77 or less (figure 9, table 1), and the mass-fraction of stage-one hybrid magma contained within stage-two mixed magmas is 0.5 or less (figure 9). The mixing proportions in both stages of the model are within the rheological limits for mechanical stirring, given the compositions of the mixing magmas (see Sparks and Marshall 1987, figure 5, page 111 ). In contrast, a considerable 
rheological barrier would have prevented the direct mixing of the mantle-derived mafic and crustalderived felsic end-member magmas sufficient to produce many of the intermediate rocks at Mt. Perkins (58-64 $\mathrm{SiO}_{2}$ range). A combination of fractional crystallization and small amounts of magma mixing allowed stage-one hybrid magmas to evolve to a composition with rheological properties capable of mixing with the felsic magma. Thus our two-stage model, with its component of fractional crystallization, provides a mechanism by which magma mixing can play a significant role in the production of a wide-range of intermediate magmas, despite the rheological problems associated with the mixing of compositionally contrasted mafic and felsic magmas.

The quenched nature of the Mt. Perkins magmas allows the interpretation of the precommingling history of the magma system. If these commingled magmas had been allowed to cool slowly (as would be the case in larger plutons emplaced within hotter country rocks), isotopic diffusion would have significantly altered the precommingling isotopic compositions. Mt. Perkins rocks would then have acquired isotopic signatures similar to those of commingled plutonic suites (i.e., a narrow range overall range of $\epsilon_{\mathrm{Nd}}$ and $\mathrm{Sr}_{\mathrm{i}}$ values, little or no differences in enclave-host rock isotopic values, and in the most mafic rocks a mod- erately negative $\epsilon_{\mathrm{Nd}}$ and $\mathrm{Sr}_{\mathrm{i}}$ above 0.706 ). If isotopic diffusion had occurred, most of the isotopic evidence of the earlier open-system evolution and information about the end-mernber magmas would have been lost. Because trace element diffusion is slower than isotopic diffusion, the trace element trends would have been preserved and the rocks of the Mt. Perkins pluton would still record the fractional crystallization event. Post-commingling isotopic diffusion among the Mt. Perkins magmas, therefore, could have produced a suite of commingled rocks with compositions entirely consistent with the autolith model. Many of the world's commingled plutonic suites may have evolved like the Mt. Perkins magmas, but the evidence for magma hybridization processes may have been obliterated by isotopic diffusion during slow cooling.

\section{ACKNOWLEDGMENTS}

This work was supported by a grant from the Nevada Nuclear Waste Project Office to E. I. Smith. We thank J. E. Faulds for sharing his knowledge of the regional geology, and Calvin Miller and Claudia Falkner for numerous discussions regarding magma mixing processes and Tertiary plutonism. Careful reviews provided by J. E. Faulds, Gene Yogodzinski, David Weide and two anonymous referees are gratefully acknowledged.

\section{REFERENCES CITED}

Allen, C. M., 1991, Local equilibrium of mafic enclaves and granitoids of the Turtle pluton southeastern California: mineral, chemical, and isotopic evidence: Am. Mineral., v. 76, p. $574-588$.

Arth, J. G, and Hanson, G. N., 1975, Geochemistry and origin of the early Precambrian crust of northwestern Minnesota: Geochim. Cosmochim. Acta, v. 30, p. 325-362.

Bateman, P. C., 1989, Constitution and genesis of the central part of the Sierra Nevada Batholith, California: U.S. Geol. Survey Prof. Paper 1483, 189 p.

Baker, D. R., 1989, Tracer versus trace element diffusion: diffusional decoupling of Sr concentration from $\mathrm{Sr}$ isotope composition: Geochim. Cosmochim. Acta, v. 53, p. 3015-3023.

-1990, Chemical interdiffusion of dacite and rhyolite: anhydrous measurements at $1 \mathrm{~atm}$ and $10 \mathrm{kbar}$, application to transition state theory, and diffusion in zoned magma chambers: Contrib. Mineral. Petrol., v. 104 , p. 407-423.

Barbarin, B., 1991, Enclaves of the Mesozoic calcalkaline granitoids of the Sierra Nevada batholith,
California, in Didicr, J., and Barbain, B., eds., Enclaves and Granite Petrology (Developments in Petrology 13): Amsterdam, Elsevier, p. 135-154.

$\longrightarrow$, and Didier, J., 1992, Genesis and evolution of mafic microgranular enclaves through various types of interaction between coexisting felsic and mafic magmas, in Brown, P. E., and Chappell, B. W., cds., The second Hutton symposiurn on the origin of granites and related rocks: Royal Soc. (Edinburgh) and Geol. Soc. America Spec. Paper 272, p. 145-154.

Bennett, V. C., and DePaolo, D. J., 1987, Proterozoic crustal history of the western United States as determined by Neodymium isotopic mapping: Geol. Soc. America Bull., v. 99, p. 674-685.

Christensen, R. L., and Lipman, P. W., 1972, Cenozoic volcanism and plate tectonic evolution of the western United States; 2. Late Cenozoic: Royal Soc. (London) Philos. Trans. series A, v. 271, p. 249-284.

Davidson, J. P.; De Silva, S. L.; Holden, P.; and Haliday, A. N., 1990, Small-scale disequilibrium in magmatic inclusion and its more silicic: host: Jour. Geophys. Res., v. 95, p. 17,661-17,675. 
Drake, M. J., and Weill, D. F., 1975, Partition of Sr, Ba, $\mathrm{Ca}, \mathrm{Y}, \mathrm{Eu}^{2+}, \mathrm{Eu}^{3+}$, and other REE between plagioclase feldspar and magmatic liquid: an experimental study: Geochim. Cosmochim. Acta, v. 39, p. 689-712.

Decr, W. A.; Howic, R. A.; and Zussman, J., 1972, An Introduction to the Rock-Forming Mincrals: London, Longman, $528 \mathrm{p}$.

DePaolo, D. J., 1981, Trace element and isotopic effects of combined wall-rock assimilation and fractional crystallization: Earth Planet. Sci. Letters, v. 53, p. 189-202.

models and $\mathrm{Nd}-\mathrm{Sr}$ isotopic patterns: Gcochim. Cosmochim. Acta, v. 43, p. 615-630.

Dodge, F. W. C., and Kistler, R. W., 1990, Some additional observations on inclusions in the granitic rocks of the Sierra Nevada: Jour. Geophys. Res., v. 95, p. $17,841-17,848$.

Dorais, M. J.; Whitney, J. A.; and Roden, M. F., 1990, Origin of mafic enclaves in the Dinkey Creek pluton, central Sierra Nevada Batholith, California: Jour. Petrol., v. 31, p. 853-881.

Eichelberger, J. C., 1975, Origin of andesite and dacite: evidence of mixing at Glass Mountain in California and at other circum-Pacific volcanoes: Gcol. Soc. America Bull., v. 86, p. 1381-1391.

Falkner, C. M.; Miller, C. F.; Wooden, J. L.; and Heizler, M. T., 1995, Petrogenesis and tectonic significance of the calc-alkaline, bimodal Aztec Wash pluton, Eldorado Mountains, Colorado River extensional corridor: Jour. Geophys. Res., v. 100, p. 10,453-10,476.

Faulds, J. E., 1993, The Mt. Perkins block, northwestern Arizona: an exposed cross-section of a tilted synextensional volcano in a highly extended terrane: Geol. Soc. America Abs. with Prog., v. 25, p. 36.

—; Geissman, J. W.; and Mawer, C. K., 1990, Structural development of a major extensional accommodation zone in the Basin and Range Province, northwestern Arizona and southern Nevada: implications for kinematic models of continental extension, in Wernicke, B. P., ed., Basin and Range Extensional Tectonics near the latitude of Las Vegas, Nevada: Geol. Soc. America Mem. 176, p. 37-76.

-; Gans, P. B.; and Smith, E. I., 1994, Spatial and temporal patterns of extension in the northern Colorado River extensional corridor, northwestern Arizona and southern Nevada: Geol. Soc. America Abs. with Prog., v. 26, p. 351.

Feuerbach, D. L.; Smith E. I.; Walker, J. D.; and Tangeman, J. A., 1993, The role of the mantle during crustal extension: Constraints from geochemistry of volcanic rocks in the Lake Mead area, Nevada and Arizona: Geol. Soc. America Bull., v. 105, p. 1561-1575.

Fitton, J. G., and Dunlop, H. M., 1985, The Cameroon linc, East Africa, and its bearing on the origin of oceanic and continental alkali basalt: Earth Planet. Sci. Letters, v. 72 , p. 23-28.

- James, D.; and Leeman, W. P., 1991, Basic magmatism associated with Cenozoic extension in the western United States: compositional variations in space and time: Jour. Geophys. Res., v. 96, p. $13,693-13,711$.

Fleck, R. J., 1990, Neodymium, strontium, and traceelement evidence of crustal anatexis and magma mixing in the Idaho batholith, in Anderson, J. L., ed., The nature and origin of cordilleran magmatism: Geol. Soc. America Mem. 174, p. 359-374.

Foster, D. A., and Hyndman, D. W., 1990, Magma mixing and mingling between synplutonic mafic dikes and granite in the Idaho-Britteroot batholith, in Anderson, J. L., ed., The nature and origin of cordilleran magmatism: Geol. Soc. America Mem. 174, p. 347-358.

Fourcade, S., and Javoy, M., 1991, Sr-Nd-O isotopic features of mafic microgranular enclaves and host granitoids from the Pyrenees, France: evidence for their hybrid nature and inference on their origin, in Didier, J., and Barbain, B., eds., Enclaves and Granite Petrology (Developments in Petrology 13): Amsterdam, Elscvier, p. 345-366.

Frost, T. P., and Mahood, G. A., 1987, Field, chemical and physical constraints on mafic-felsic magma interaction in the Lamark Granodiorite, Sierra Nevada, California: Geol. Soc. America Bull., v. 99, p. 272-291.

Furman, T., and Spera, F. J., 1985, Co-mingling of acid and basic magmas with implications for the origin of mafic I-type xenoliths, field and petrochemical relations of an unusual dike complex at Eagle Peak Lake, Sequoia National Park, California, USA: Jour. Volc. Geother. Res., v. 24, p. 151-178.

Glazner, A. F., 1990, Recycling of continental crust in Miocene volcanic rocks from the Mojave block, southern California, in Anderson, J. L., ed., The nature and origin of cordilleran magmatism: Geol. Soc. America Mem. 174, p. 147-168.

Holden, P.; Haliday, A. N.; Stephens, W. E.; and Henny, P. J., 1991, Chemical and isotopic evidence for mass transfer between mafic enclaves and felsic magma: Chem. Gcol., v. 92, p. 135-152.

John, B. E., and Blundy, J. D., 1993, Emplacement-related deformation of granitoid magmas, southern Adamello Massif, Italy: Geol. Soc. America Bull., v. 105, p. 1517-1541.

Koyaguchi, T., 1986, Evidence for two-stage mixing in magmatic inclusions and rhyolitic lava domes on Niijima Island, Japan: Jour. Volc. Geother. Res., v. 29, p. 71-98.

Larsen, L. L., and Smith, E. I., 1991, Mafic enclaves in the Wilson Ridge Pluton, northwestern Arizona: implications for the generation of a calc-alkaline intermediate pluton in an extensional environment: Jour. Gcophys. Res., v. 95, p. 17,693-17,716.

Lesher, C. E., 1990, Decoupling of chemical and isotopic exchange during magma mixing: Nature, v. 344, p. 235-237.

- 1994, Kinetics of Sr and Nd exchange in silicate liquids: theory, experiments, and applications to uphill diffusion, isotopic equilibrium, and irreversible mixing of magmas: Jour. Geophys. Res., v. 99, p. 9585-9604. 
Menzies, M. A., 1989, Cratonic, circumcratonic anc oceanic mantle domains beneath the western United States: Jour. Geopys. Res., v. 94, p. 7899-7915.

Metcalf, R. V., and Smith, E. I., 1991, Hornblende geobarometry from two Miocene plutons: implications regarding uplift and block rotation during Basin and Range extension: Geol. Soc. America Abs. Prog., v. 23, p. A245.

-; - Martin, M. W.; Gonzales, D. A.; and Walker, J. D., 1993, Isotopic evidence of source variations in comcommingled magma systems: Colorado River extensional corridor: Geol. Soc. America Abs. with Prog., v. 25, p. 120.

Miller, C. F.; Heitzler, M. T.; Unkefer, J.; Lee, Y. F. S.; Wooden, J. L.; and Falkner, C. M., 1994, Mid-Miocene plutonism in the Eldorado Mountains, Colorado River extensional corridor: Geol. Soc. America Abs. Prog., v. 26, p. A369.

- , and Wooden, J. L., 1993, Anatexis, hybridization, and the modification of ancient crust: Mesozoic plutonism in the Old Woman Mountains area, California: Lithos, v. 32, p. 111-133.

Pin, C.; Binon, M.; Belin, J. M.; Barbarin, B.; and Clemens, J. D., 1990, Origin of microgranular enclaves in granitoids: equivocal $\mathrm{Sr}-\mathrm{Nd}$ evidence from Hercynian rocks of the Massif Central (France): Jour. Geophys. Res., v. 95, p. 17,821-17,828.

Pitcher, W. S., 1991, Synplutonic dikes and mafic enclaves, in Didier, J., and Barbarin, B., eds., Enclaves and Granite Petrology (Developments in Petrology 13): Amsterdam, Elsevier, p. 383-392.

Reid, J. B., Jr.; Evans, O. C.; and Fates, D. G., 1983, Magma mixing in granitic rocks of the central Sierra Nevada, California: Earth Planet. Sci. Letters, v. 66, p. 243-261.

Seaman, S. J., and Ramsey, P. C., 1992, Effects of magma mingling in the granites of Mount Desert Island, Maine: Jour. Geology, v. 100, p. 395-409.

Schmidt, M. W., 1992, Amphibole composition in tonalite as a function of pressure: an experimental calibration of the Al-in-hornblende barometer: Contrib. Mineral. Petrol., v. 110, p. 304-310.

Smith, E. I.; Feuerbach, D. L.; Naumann, T. R.; and Mills, J. E., 1990, Mid-Miocene volcanic and plutonic rocks of the Lake Mead area of Nevada and Arizona: production of intermediate igneous rocks in an extensional environment, in Anderson, J. L., ed., The nature and origin of cordilleran magmatism: Geol. Soc. America Mem. 174, p. 169-194.
Sparks, R. S. J., and Marshall, L. A., 1986, Thermal and mechanical constraints on mixing between mafic and felsic magmas: Jour. Volc. Geother. Res., v. 29, p. 99-124.

Sun, S. S., and McDonough, W. F., 1989, Chemical and isotopic systematics of oceanic basalts: implications for mantle composition and processes, in Saunders, A. D., and Norry, M. J., eds., Magmatism in the Ocean Basins: Geol. Soc. (Londonl) Spec. Pub., 42, p. 313-345.

Stormer, J. C., Jr., and Nicholl:s, J., 1978, XLFRAC: a program for the interactive testing of magmatic differentiation models: Computers Geosci., v. 4, p. 143159.

Turner, R. D., and Glazner, A. F., 1991, Miocene volcanism, folding, and faulting in the Castle Mountains, southern Nevada and eastern California, in Wernicke, B. P., ed., Basin and Range extensional tectonics at the latitude of Las Vegas: Geol. Soc. America Mem. 176, p. 23-35.

Vernon, R. H., 1983, Restites, xenoliths, and microgranitoid enclaves in granites: Jour. Proc. Royal Soc. New South Wales, v. 116, p. 1-22.

- 1984, Microgranitoid enclaves in granitesglobules of hybrid magma quenched in a plutonic en. vironment: Nature, v. 309, p. 438-439.

-1991 , Interpretation of microstructures of microgranitoid enclaves, in Didier, J., and Barbarin, B., eds., Enclaves and Granitoid Petrology (Developments in Petrology 13): Amsterdam, Elsevier, p. 277-292.

Watson, E. B., and Jurewicz, S. R., 1984, Behavior of alkalies during diffusive interaction of granitic xenoliths and basaltic magma: Jour. Geology, v. 92, p. 121-131.

Weibe, R. A., 1991, Commingling of contrasting magmas and generation of mafic enclaves in granitic rocks, in Didier, J., and Barbarin, B., eds., Enclaves and Granitoid Petrology (Developments in Petrology 13): Amsterdam, Elsevier, p. 393-402.

Weibe, R. A., 1994, Silicic magma chambers as traps for basaltic magmas: the Cadillac Mountain intrusive complex, Mount Desert Island, Maine: Jour. Geology, v. 102 , p. 423-438.

Wilson, M., 1989, Igneous Petrogenesis: A Global Tectonic Approach: London, Unwin, $466 \mathrm{p}$.

Wyllie, P. J.; Cox, K. G.; and Biggar, G. M., 1962, The habit of apatite in synthetic systems and igneous rocks: Jour. Petrol., v. 3, p. 233-243. 